\title{
Molecular Structure, Pathophysiology, and Diagnosis of COVID-19
}

\author{
Omar Belmehdi ${ }^{1}$ (D), Maryam Hakkour ${ }^{2}$ (D), Nasreddine El Omari ${ }^{3}$ (D), Abdelaali Balahbib ${ }^{2}$ (D) , Fatima- $^{2}$ \\ Ezzahrae Guaouguaou ${ }^{4}$ (D), Taoufiq Benali ${ }^{\text {(D) }}$, Aicha El Baaboua ${ }^{1}$ (D), Meriem Lahmoud ${ }^{(i D}$, Naoual \\ Elmenyiy $^{7 \text { (D) , Abdelhakim Bouyahya }}{ }^{8 * *}$ (D)
}

1 Biology and Health Laboratory, Biotechnology and Applied Microbiology Team, Department of Biology, Faculty of Science, Abdelmalek-Essaadi University, Tetouan, Morocco

2 Laboratory of Biodiversity, Ecology, and Genome, Faculty of Sciences, Mohammed V University in Rabat, Rabat, Morocco

3 Laboratory Laboratory of Histology, Embryology, and Cytogenetic, Faculty of Medicine and Pharmacy, Mohammed V University in Rabat, Morocco

4 Mohammed V University in Rabat, LPCMIO, Materials Science Center (MSC), Ecole Normale Supérieure, Rabat, Morocco

5 Laboratory of Natural Resources and Environment, Polydisciplinary Faculty of Taza, Sidi Mohamed Ben Abdellah University of Fez B.P.: 1223, Taza-Gare, Taza, Morocco

6 Faculty of Medicine and Pharmacy, Cadi Ayyad University, Marrakesh, Morocco

7 Laboratory of Physiology, Pharmacology \& Environmental Health, Faculty of Science, University Sidi Mohamed Ben Abdellah, Fez, Morocco

8 Laboratory of Human Pathologies Biology, Department of Biology, Faculty of Sciences, and Genomic Center of Human Pathologies, Faculty of Medicine and Pharmacy, Mohammed V University in Rabat, Morocco

* Correspondence: boyahyaa-90@ hotmail.fr;

Scopus Author ID 57190813643

The implication for health policy/practice/research/medical education: all physiopathological aspects should be taken into account during diagnosis for a better medication of COVID-19 patients.

Received: 22.09.2020; Revised: 10.10.2020; Accepted: 12.10.2020; Published: 14.10.2020

Abstract: Recently, a new coronavirus, named Severe Acute Respiratory Syndrome-Coronavirus 2 (SARS-CoV-2) has emerged in Wuhan, Hubei province, China. SARS-CoV-2 caused a global epidemic (COVID-19), which continues to kill thousands of people around the world today. With an exclusively interhuman transmission mode, in the absence of a vaccine, the spreading of this new coronavirus is accelerating remarkably. With the studies of the molecular biology of the virus, molecular and serological diagnostic tests are implemented. However, the pathophysiology is not well understood and variable, which gives different symptoms, with a significant mortality rate. Indeed, several organs such as the lungs, brain, kidneys, immune system, and heart are affected directly and/or indirectly.

Keywords: COVID-19; SARS-CoV-2; pathophysiology; clinical diagnosis.

(C) 2020 by the authors. This article is an open-access article distributed under the terms and conditions of the Creative Commons Attribution (CC BY) license (https://creativecommons.org/licenses/by/4.0/).

\section{Introduction}

Recently, a new coronavirus, named Severe Acute Respiratory Syndrome- Coronavirus 2 (SARS-CoV-2), caused by one of the Darwinian adaptive mutations, has produced an epidemic threat to global public health. The disease caused by SARS-CoV-2 has been named COVID-19 (Coronavirus disease 2019) by the world health organization (WHO). This virus was found at the end of 2019 in Wuhan, Hubei province in China, and currently, it is a real pandemic, with countries all over the globe recording a massive increase in COVID-19 patients $[1,2]$. This virus continues to cause real health dangers, leading to the death of many people 
and causing enormous social, psychological, and economic impacts [3]. This virus is originated from a zoonotic and transmitted to humans via animals such as bats and others, then progressed to be transmitted from human-to-human $[4,5]$.

The most common clinical symptoms of patients infected by SARS-CoV-2 include dry cough, high fever $\left(>38^{\circ} \mathrm{C}\right)$, fatigue, and some other symptoms such as vomiting, myalgia, sputum production, headache, dyspnea, hemoptysis, and diarrhea [6-8]. It is well known that in the case of acute respiratory infections, the Real-Time Polymerase Chain Reaction (RTPCR) technique is routinely used to detect the causative viruses, from respiratory secretions, for early diagnosis of infected patients. This technique has also been used for the qualitative detection of the new coronavirus (SARS-CoV-2). In addition, other serological tests are used in order to reveal viral antigens [9].

While specific antiviral therapeutics and vaccines are the most effective methods to prevent and treat a viral infection, up to date, there is any specific drug against the new coronavirus [10], and the lockdown is the only alternative solution to prevent and reduce the risk of transmission of this virus. Moreover, several studies are now being undertaken to set up treatments that target virus checkpoints such as penetration, de-encapsulation, transcription, replication, and assembly.

In this review, genomic and molecular structures, as well as the viral cycle of SARSCOV-2are highlighted. Transmission ways, clinical characteristics, molecular pathophysiology, and diagnosis are discussed.

\section{Molecular Structure and Pathogenic Mechanism of SARS-CoV-2}

\subsection{Structure and morphology.}

The coronaviruses constitute a group of viruses belonging to the Coronaviridae family. SARS-CoV-2, which belongs to the $\beta$-coronavirus genus with MERS-CoV and SARS-CoV, has a round or elliptic and often pleomorphic form [11], enveloped, and measuring between 60-140nm in diameter [12].

CoVs are positive-stranded RNA viruses; they contain four major structural proteins on their surface: the membrane protein $\mathrm{M}$, the envelope protein $\mathrm{E}$, and the spicule $\mathrm{S}$. In fact, the projection of the spike on the virus surface that causes the corona (Latin: crown) appearance. Inside the virion, a vacuum separating the inner core from the envelope was observed using cryoelectron microscopy. These cores are formed by the genomic RNA associated with the nucleoprotein N (Figure 1).

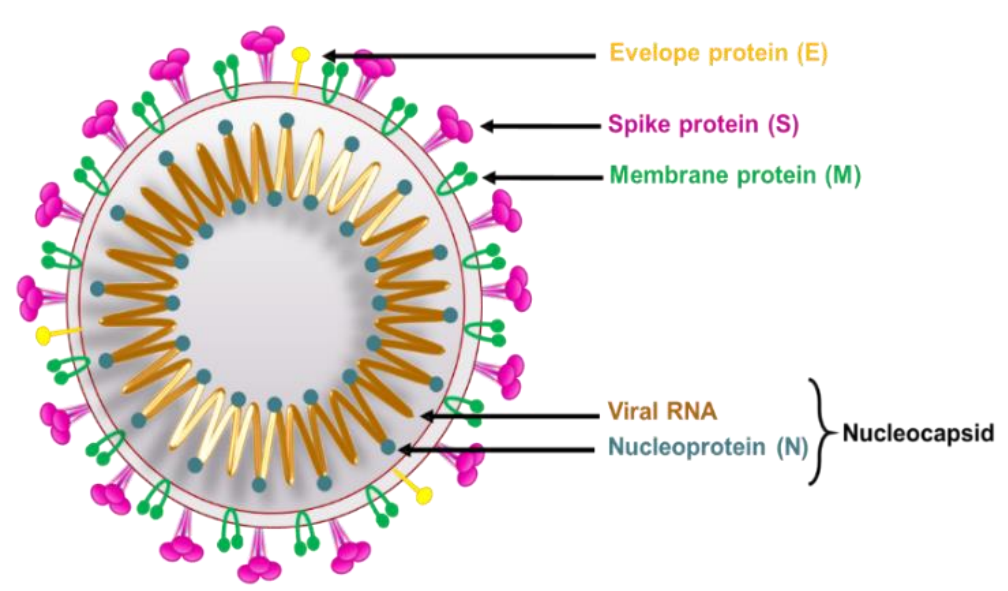

Figure 1. Schematic representation of the SARS-CoV-2 structure. 


\subsection{Genome organization.}

The genome is a single strand RNA of positive polarity [13], a cap at the 5'end, and a polyadenylated tail (polyA) at the 3' end [14]. It is one of the largest RNA viral genomes with a size between 27.6 and $31.5 \mathrm{~kb}$. The coronavirus RNA consists of a cap at the 5' end followed by a leader sequence (64 nt) and a 5' untranslated region (5'-UTR) containing several secondary structures necessary for replication and transcription [15-17]. At the 3' end of the genome, there are 507-528 UTR nucleotides, followed by a poly (A) sequence of variable length. Several open reading frames (ORFs) are present, and at least ten have been detected [16, 17]: ORF1ab non-structural protein, ORF2 spike S glycoprotein, ORF3a, 3b and 3c protein-small envelope (E), ORF4, membrane glycoprotein (M), ORF5ab and nucleoprotein N ORF6.

About 2/3 of the viral RNA is occupied by the open reading frames ORF1a and ORF1b. The remaining third includes genes encoding structural proteins and non-structural proteins. The genes, unchanged among all members of the coronavirus family, are arranged in a specific order: 5'-replicase $-\mathrm{S}-\mathrm{E}-\mathrm{M}-\mathrm{N}-3$ ' (Figure 2).

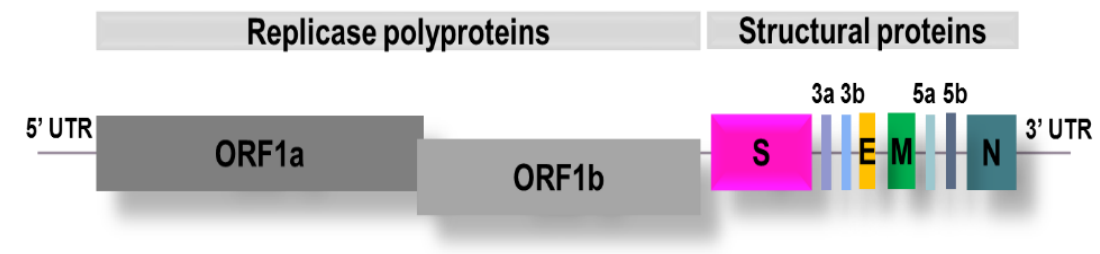

Figure 2. Schematic organization of the coronavirus genome.

\subsection{Viral proteins.}

SARS-CoV-2 genome was always suggested to have 16 predicted non-structural proteins constituting a polyprotein (ORF1ab), followed (at least) by 13 downstream open reading frames (ORF): surface glycoprotein (or Spike), ORF3a, ORF3b, Envelope, Membrane, ORF6, ORF7a, ORF7b, ORF8, Nucleocapsid, ORF9a, ORF9b, and ORF10, referred as wS, wORF3a, wORF3b, wE, wM, wORF6, wORF7a, wORF7b, wORF8, wN, wORF9a, wORF9b, and wORF10, respectively.

However, a recent comparative modeling study made it possible to structurally characterize 17 individual proteins, including 13 non-structural proteins of wORF1ab (wNsp1, wNsp3, wNsp4, wNsp5, wNsp7, wNsp8, wNsp9, wNsp10, wNsp12, wNsp14, wNsp15, $w N s p 16$ ), three structural proteins (wS, wE, and wN), as well as one ORF (wORF7a) [18].

\subsubsection{Spike protein.}

The spike protein (SProtein) plays a major role in cell attachment, antigenic recognition, viral fusion, and antibody neutralization induction [19]. This transmembrane type I protein is cleaved into two subunits $\mathrm{S} 1$ and $\mathrm{S} 2$. Indeed, all the S proteins of the different coronaviruses share this organization in two domains; however, a difference lies in their cleavage [20].

The $\mathrm{S} 1$ region is located at the $\mathrm{N}$-terminal part, forms an ectodomain, and allows recognition and binding to its cellular receptor. This region consists of four domains $(\mathrm{A}, \mathrm{B}, \mathrm{C}$, and D) and the cell Receptor Binding Domains (RBD), which are located in the S1 domain [21]. In addition, this $S 1$ subunit contains most of the epitopes recognized by neutralizing antibodies during infection [22]. 
Indeed, most of the coronaviruses use separate domains of the S1 subunit to recognize different receptors of attachment and input. Unlike other human coronaviruses and MERSCoV S, SARS-CoV, and several SARS-related coronaviruses interact directly with the Angiotensin-Converting Enzyme 2 (ACE2) via B Domain (SB) to enter target cells.

ACE2 acts as a functional receptor for SARS-CoV-2, which commits with an affinity comparable to SARS-CoV SB. This close link with this receptor could explain the efficient transmission of this newly emerged human coronavirus. Furthermore, a new characteristic that distinguishes this virus from SARS-CoV and SARSr-CoV, which is the presence of a cleavage site, cleaved during biosynthesis, of furin at the S1/S2 limit.

Although the SARS-CoV S1 subunit has a V-shaped architecture like other coronaviruses, the opening of SARS-CoV-2 SB is necessary to interact with ACE2 on the surface of the host cell and initiate the changes in conformation, leading to cleavage of the S2's site, and the fusion of the membrane and viral entry. However, the conformational variability of the SB domains has been observed. Indeed, studies on the three-dimensional (3D) structure of SB domains revealed the presence of several conformational states of SARS-CoV-2 S. Some of the trimers hosting a single open SB domain while the remaining half was represented by trimers closed with the three closed SB domains. A recently determined SARS-CoV-2 S structure also detected trimers with a single open SB domain but none fully closed.

\subsubsection{Membrane protein.}

The membrane protein is the most abundant in the envelope; it plays a key role in the assembly of the virion and interacts with other structural proteins $(\mathrm{N}, \mathrm{S}$, and $\mathrm{E})$. This protein is exposed inside the viral envelope. The C-terminus, also known as the end domain, makes up about half of the protein and is inside the virion. However, the N-terminal end also called an ectodomain, is located outside the virion. This protein plays a major role in the conditioning of viral RNA by interacting specifically with the latter's conditioning signal [23]

\subsubsection{Nucleocapsid protein.}

The protein $\mathrm{N}$ is a highly basic phosphoprotein that combines with RNA to form the helical nucleocapsid. Protein N also interacts with protein M, and it is surrounded by a lipid bilayer in which the envelope proteins $\mathrm{S}, \mathrm{M}$, and $\mathrm{E}$ are embedded. From a role perspective, this protein is involved in the processes linked to the viral genome. Moreover, it is also involved in the virus replication cycle and the host's cellular response to viral infection [18].

\subsubsection{Envelope protein.}

The protein $\mathrm{E}$ is the smallest among the structural proteins; it is the fewest abundant but the most enigmatic. It lacks a cleavable signal peptide that classifies it among the type II transmembrane proteins. Its role is well defined in the assembly and budding of coronavirus particles. In addition, it is very important in the production and maturation of the virus; the coronaviruses lacking $\mathrm{E}$ have significantly reduced viral titers and crippled viral maturation or yield propagation, incompetent progeny. It has a short $\mathrm{N}$-terminal end, followed by a transmembrane domain, and then a C-terminal end constituting the majority of the protein [18]. 


\subsubsection{Non-structural proteins.}

The non-structural proteins of coronaviruses are generally non-essential for virus replication. One of these non-structural proteins is the replicase encoded by gene 1 and located in the first two-thirds of the genome. There is also a rep gene that codes for two reading frames (ORF1a and ORF1b). These two ORFs are translated into two polyproteins: pp1a and pp1ab, which are themselves cleaved by two viral proteases allowing the release of 13 non-structural proteins (nsps) [18].

Nsp1 is a non-structural protein used by SARS-CoV-2 to inhibit the innate immune system. Indeed, this protein modulates the Calcineurin/NFAT pathway, which activates immune cells [24]. However, the overexpression of Nsp1 is implicated in the immunopathological diseases via the deregulation of cytokines, as observed in severe cases of SARS.

The intra-viral hetero-oligomeric complexes included the interactions between the nonstructural proteins (Nsp7, Nsp8, Nsp10, Nsp12, Nsp14, and Nsp16) exclusively. The interaction with host cells includes non-structural protein Nsp3 (papain-like protease, PLpro, domain) (interact with human ubiquitin-aldehyde), surface $\mathrm{S}$ protein (interact with human ACE2receptor), and S protein (interact with several neutralizes antibodies) [18].

\subsection{Replication of coronaviruses.}

\subsubsection{Attachment, penetration, and uncoating.}

Although coronaviruses generally attach to cells through the ubiquitous acetylated forms of glycoproteins and lipids, specific binding between the virus and a cellular receptor is required to establish a viral infection.

The coronavirus glycoprotein $\mathrm{S}$ is responsible for attachment and mediates viral entry. Indeed, the entry begins with a binding of the surface unit S1 to a cellular receptor via the Receptor Binding Domain (RBD). Thereafter, priming of S protein is necessary, which induces the cleavage of $S$ at the $S 1 / S 2$ sites, then the viral and cellular membranes fuse through the $S 2$ subunit [25].

SARS-CoV interacts directly with the ACE2 receptor expressed on the surface of pneumocytes via domain $B$ of the $S 1$ subunit and uses the cellular serine protease TMPRSS2 for S protein priming [26-28]. SARS-CoV may also use the endosomal protease cysteine cathepsin $\mathrm{B}$ and $\mathrm{L}(\mathrm{CatB} / \mathrm{L})$ for $\mathrm{S}$ protein priming [29]. However, only TMPRSS2 activity is essential for viral spread and pathogenesis in the infected host [30].

The binding of the virus to the receptor leads to a conformational change in the $\mathrm{S}$ protein. The cleavage of this protein, carried out at low $\mathrm{pH}$, induces the fusion of the viral envelope and the endosomal membrane leading to the release of the viral genome in the cell cytoplasm, which will be ready for translation and transcription.

\subsubsection{Translation and transcription of viral RNA.}

After the release of viral RNA in the cytoplasm, the first synthetic event is the translation of the viral genome in order to produce RNA-dependent RNA polymerase translated from gene 1. SARS-CoV gene 1, as for all coronaviruses, contains two overlapping ORFs (1a and $1 \mathrm{~b}$ ), which are translated to pp1a and pp1ab polyproteins using a ribosomal frame-shifting mechanism. These two polyproteins (ppla and pplab) then undergo proteolytic maturation 
allowing the production of non-structural proteins (NSP) that assemble into the replicasetranscriptase complex to promote subgenomic mRNA synthesis. Indeed, this replicase/transcriptase complex allows the replication of the coronavirus RNA (+) to a genomic coronavirus RNA (-), which is used to produce full-length genomic RNA [31].

On the other hand, during the synthesis of the viral RNA (-), a discontinuous transcription can take place, inducing the production of subgenomic RNA (+). In the mRNA exist the body TRSs that correspond to the structural proteins. In fact, during mRNA transcription, the RNA-dependent RNA polymerase stops at each corresponding body TRS and jumps the entire TRS leader sequence to amplify the leader sequence located at the 5'end of the genome (Figure 3).

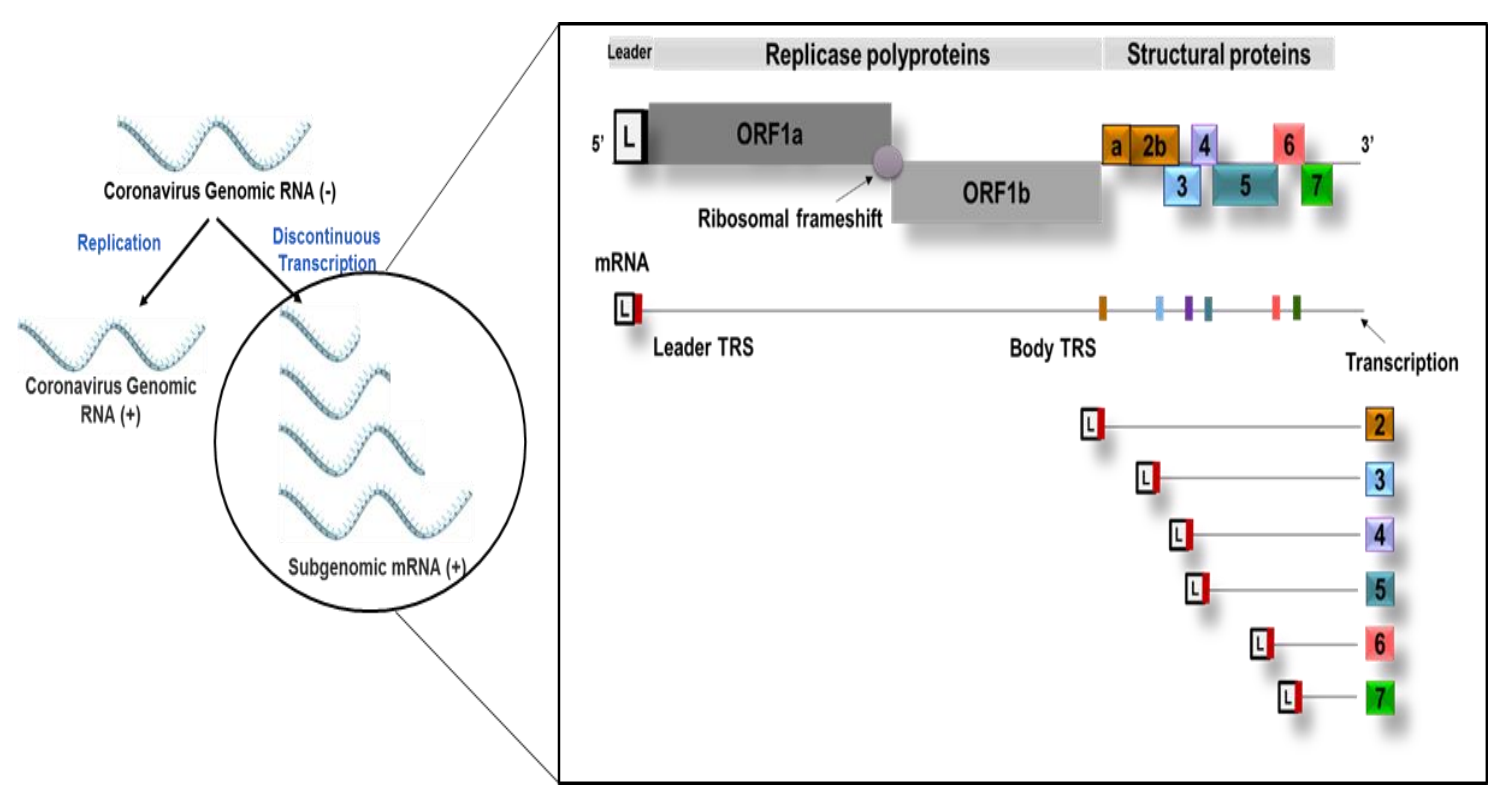

Figure 3. Coronavirus subgenomic synthesis.

The four structural proteins: spike (S), membrane (M), envelope (E) proteins, and nucleocapsid $(\mathrm{N})$, are translated from separate mRNA to form the viral proteins, which constitute the virion progeny (Figure 4).

\subsection{Replication of viral genomic RNA.}

Unlike the discontinuous synthesis of subgenomic RNA, genomic RNA requires continuous synthesis using negative models. During replication, in addition to the replicase gene, some specific secondary structures are required for genomic RNA replication besides the 5'and 3' terminal UTR sequences [32]. The leader sequence of the virus can be quickly replaced by that of the helper virus, suggesting that RNA replication also involves a free RNA template in a similar way to transcription.

\subsubsection{Assembly and release.}

After replication, the structural proteins are translated and inserted into the endoplasmic reticulum, then moved to the Golgi compartment. The viral genomic RNA is conditioned in the nucleocapsid, and then the envelope proteins are incorporated during the budding stage to form mature virions. A strong interaction between $\mathrm{E}$ and $\mathrm{M}$ proteins occurs. Indeed, protein $\mathrm{E}$ provides a temporary anchor to move $\mathrm{M}$ in pre-Golgi compartments in order to prepare the membranes for budding [33]. The spike protein (S) contains the signal for recovery of the 
endoplasmic reticulum, which plays an important role in the accumulation of proteins near the budding sites [34]. After budding, the viral particles are transported through a functional Golgi stack and released from host cells by the exocytic pathway (Figure 4).

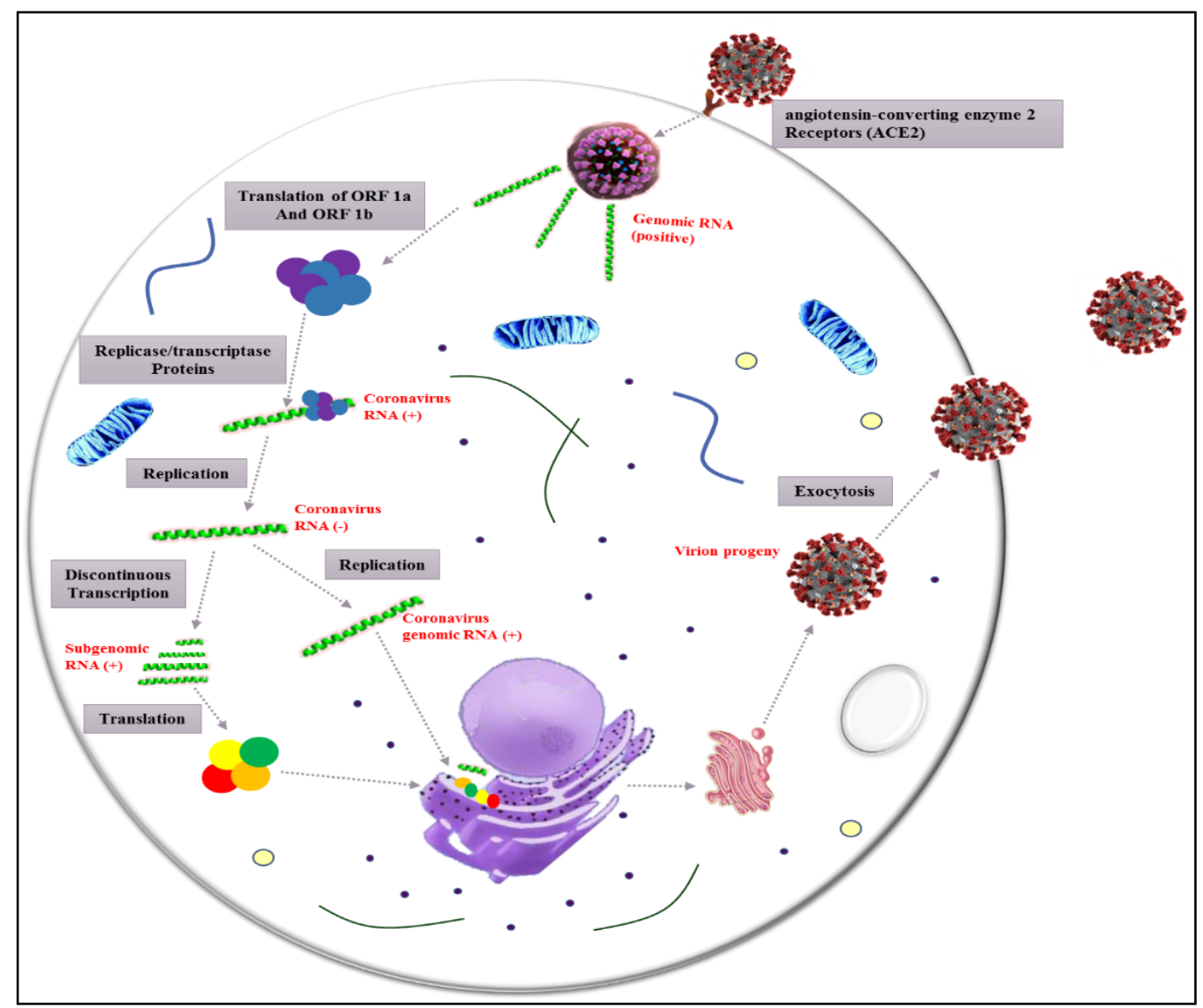

Figure 4. Replication cycle of SARS-CoV-2. The viral cycle of SARS-Cov-2 requires four steps. 1) Attachment, penetration, and uncoating: in which the virus binds toACE2 of the cell host to penetrate into the cytoplasm and releases its nucleic acid (RNA+). 2) Translation and transcription: SARS-CoV translates its two overlapping ORFs (1a and 1b) into ppla and pplab polyproteins using a ribosomal frame-shifting mechanism. These two polyproteins (ppla and pplab) then undergo proteolytic maturation allowing the production of non-structural proteins (NSP) that assemble into the replicase-transcriptase complex to promote subgenomic mRNA synthesis. This replicase/transcriptase complex will allow replication of the RNA coronavirus (+) to a genomic RNA coronavirus (-) which is used to produce full-length genomic RNA. Then structural proteins are (S, M, E, and N) are also translated from separate mRNA to give the viral proteins. 3) Replication: The replication of genomic RNA requires continuous synthesis using negative models. During this replication, some specific secondary structures are required for genomic RNA replication beside the 5'and 3' terminal UTR sequences. 4) Assembly and release: the structural proteins are translated and inserted into the endoplasmic reticulum, then are moved to the Golgi compartment. The viral genomic RNA is conditioned in the nucleocapsid, and then the envelope proteins are incorporated during the budding stage to form mature virions. After budding, the viral particles are transported through a functional Golgi stack and are released from host cells by the exocytic pathway.

\section{Transmission and Clinical Characteristics}

\subsection{Transmission.}

COVID-19 infection is a zoonotic disease transmitted to humans via bats, and other animals, in which bats are considered as the primary host $[4,5]$. According to current evidence, the cause of spreading of SARS-CoV-2 in non-infected countries is the entry of infected passengers coming from infected countries because of poor screening at the airports.

Without any doubt, the reported cases in Korea and China [35, 36] and also the proposed mechanism by Yen et al.[37] have proven that the predominant route of this pandemic disease is based on a circular trajectory from the community, hospital to the community again, 
all along the incubation period in asymptomatic carriers of COVID-19and in which airborne hypothesis is the first step in this contaminating cycle [37]. Indeed, several clinical and epidemiological studies have linked the infection to fast-spreading among humans because of their existence in public events and through direct contact with an infected person or respiratory droplets (coughing, sneezing). The virus can penetrate the human body via inhalation from the mouth or nose [38-40]. Other possible sources, inside the local community, can be occurred during indirect contact with contaminated surfaces, soils, and feces [41]. However, up to date, according to WHO, there is no report of fecal-oral transmission of SARS-CoV-2.

A group of researchers has implemented mathematical models for better understanding the dynamics of human-to-human infection showed that the reproduction number of COVID19 cases follows an exponential growth trend, which explains the high number of contaminated people reported worldwide [36, 42].

Hospitals and clinics are the second amplification loop ofCOVID-19. The previous study directed by Kwatra et al. [43] has demonstrated that the skin of healthcare workers and a long time of gloves wearing are frequent risk factors in hospitals [43]. Moreover, other findings supported that fomites (particularly medical staff), patients, and hospital visitors are an important contributor in COVID-19 outbreaks. The relatively long period of incubation, false negatives, and asymptomatic period in COVID-19 cases let the virus circulate secretly between hospital visitors in waiting rooms crowded by both ill and healthy people. At that moment, coronavirus infection spread among both healthcare workers and visitors of hospitals, and when returning home, they re-infect their communities. The progression of this mechanism develops a continuous cascade of contamination inside the society [35, 36].

\subsection{Clinical characteristics}

The infection of COVID-19 causes several symptoms after an incubation period of approximately 2 to 5 days, which are similar to those of seasonal allergies and influenza [5,7]. However, other symptoms appear to be unique for COVID-19, such as rhinorrhea, sore throat, and sneezing [7].

According to the WHO and other authors, the clinical diagnosis of COVID-19 is highly based on epidemiological history as the main screening criteria for SARS-CoV-2 (contact with confirmed COVID-19 patients within 14 days of symptom onset or travel history) [44-46]. Essentially, the most common clinical symptoms in patients infected with COVID-19 at onset are mainly fever $\left(\geq 38^{\circ} \mathrm{C}\right)$, breathing difficulty after one week of the onset of disease, dry cough, and fatigue. Other symptoms are also observed, such as sputum production, headache, hemoptysis, myalgia, vomiting, diarrhea, dyspnea, and lymphopenia [6, 7].

Generally, pregnant women are more susceptible to respiratory pathogens and severe pneumonia because they are at an immunosuppressive state, and physiological adaptive changes during pregnancy (diaphragm elevation, edema of respiratory tract mucosa, and increased oxygen consumption) can render them intolerant to hypoxia [47].

It has been suggested that SARS-CoV-2 causes damages to vital functions other than the lung, renal, and liver function [48]. Indeed, ocular surface infection in patients with COVID-19 with SARS-CoV-2 RNA detected in eye secretions has also been observed [41]. However, other complications are present in COVID-19 patients and include acute heart injury, secondary infections, and acute respiratory distress syndrome [44].

On the other hand, it has been showing recently that there are co-infections between seasonal coronaviruses and influenza A or B viruses and rhino/enteroviruses. However, there 
is no cross-reaction between other coronaviruses, and SARS-CoV-2 has not yet been described [49].

\section{Pathophysiology of COVID-19}

Up to date, there is a lack of information about the pathophysiology of COVID-19 due to the sudden outbreak and high speed of spreading of SARS-CoV-2. The similarity with SARS-CoV allowed understanding in some ways the pathogenesis of SARS-CoV-2 infection. The most relevant is the ACE2 cellular receptor, which is the same for the two viruses. The only difference is that the affinity of ACE2 is higher for SARS-CoV-2, which explains its high degree of contamination. The respiratory tract is clearly the most important site of infection, but it was reported that SARS-CoV affects several organs in the human body such as the lungs, heart, spleen, lymph nodes, liver, brain, gastrointestinal tract, and blood vessels (Figure 5). The pathological effects of SARS-CoV might be the result of a direct cytopathic action caused by mediated local replication of the virus or indirect action, which is the result of respiratory failure and overreaction of the immune system [50], which made it a very complicated disease. In this part, we discuss the pathophysiology of SARS-CoV-2 based on what it is already known about SARS-CoV-2 and SARS-CoV infections.

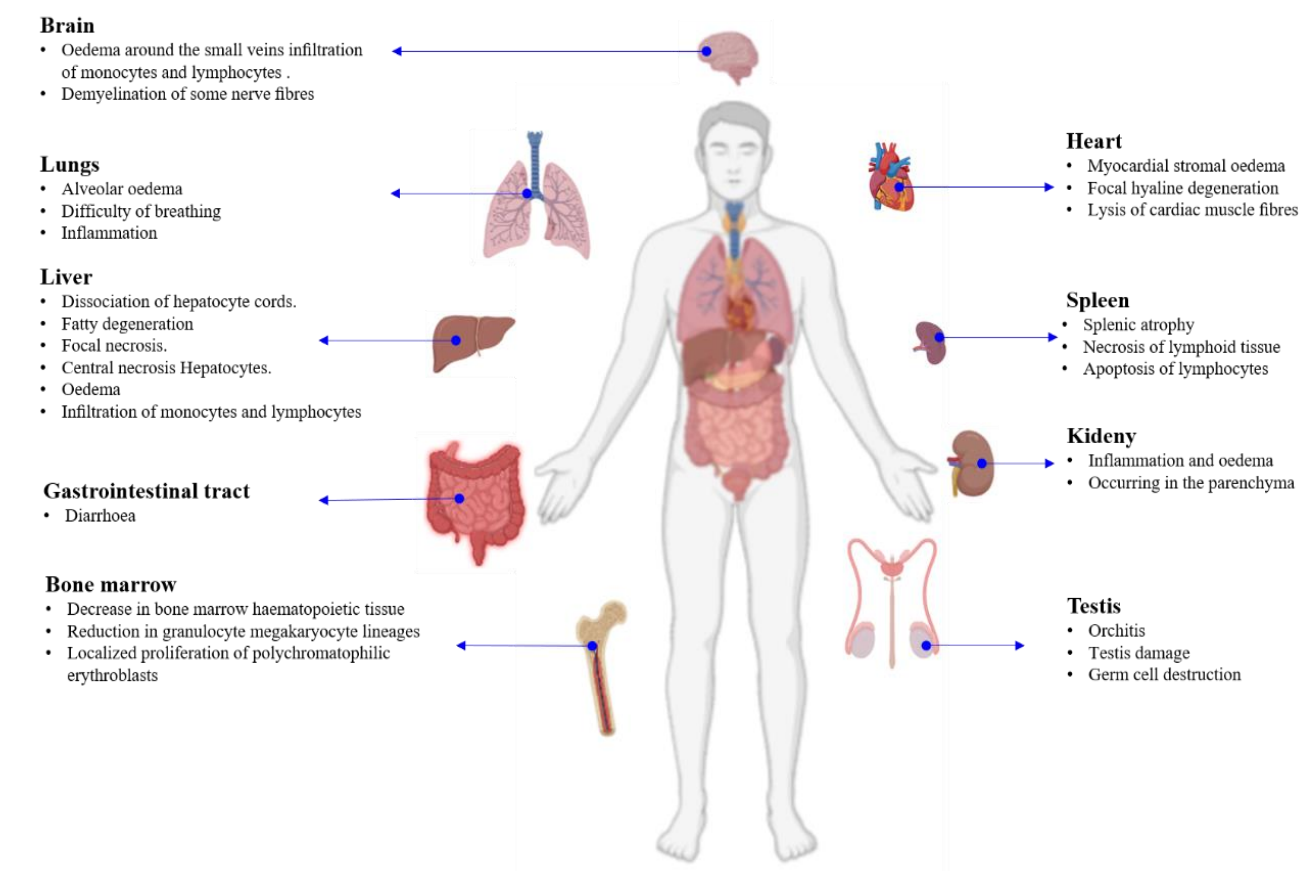

Figure 5. Pathophysiology of COVID-19 in human organs.

\subsection{Pathophysiology on the respiratory tract.}

Pathologic examinations of two patients who died from COVID-19 revealed that the lungs of both patients exhibited edema, proteinaceous exudate, focal reactive hyperplasia of pneumocytes with patchy inflammatory cellular infiltration, and multinucleated giant cells [51]. These pathologies are highly similar to those induced by SARS-CoV [52, 53]. The virus enters the cell host by its spike protein through the ACE2 receptor [54]. After its replication by exploiting cell machinery, the virus released outside the cell, and the cell host was damaged. The damage of the cell releases inflammatory substances known as danger-associated molecular patterns (DAMPs). These molecules are recognized by their receptors on the surface of macrophage, called pattern recognition receptors (PRRs). The macrophage releases pro- 
inflammatory cytokines such as IL-1, IL-6 [55, 56]. Also, chemokines are released by the epithelial cells, which result in severe local inflammation in the lungs. On the other hand, these cytokines such as IL-6 and TNF- $\alpha$, may cause the increase of blood capillaries permeability, which leads to leakage of fluid from the blood to alveoli, and as a result, alveolar edema occurs.

The fluid leakage and the infiltration of immune cells cause the consolidation of alveoli, which may alter gaze exchange and lead to hypoxemia as a consequence (Figure 6). Moreover, the viral infection can be followed by a bacterial infection, which aggravates lung injury [57]. The possibility of ACE2-associated lung injury has been also reported [58]. Loss of ACE2 function may enhance inflammation and increase vascular permeability, which can lead to edema and immune cell infiltration [58] (Figure 6).

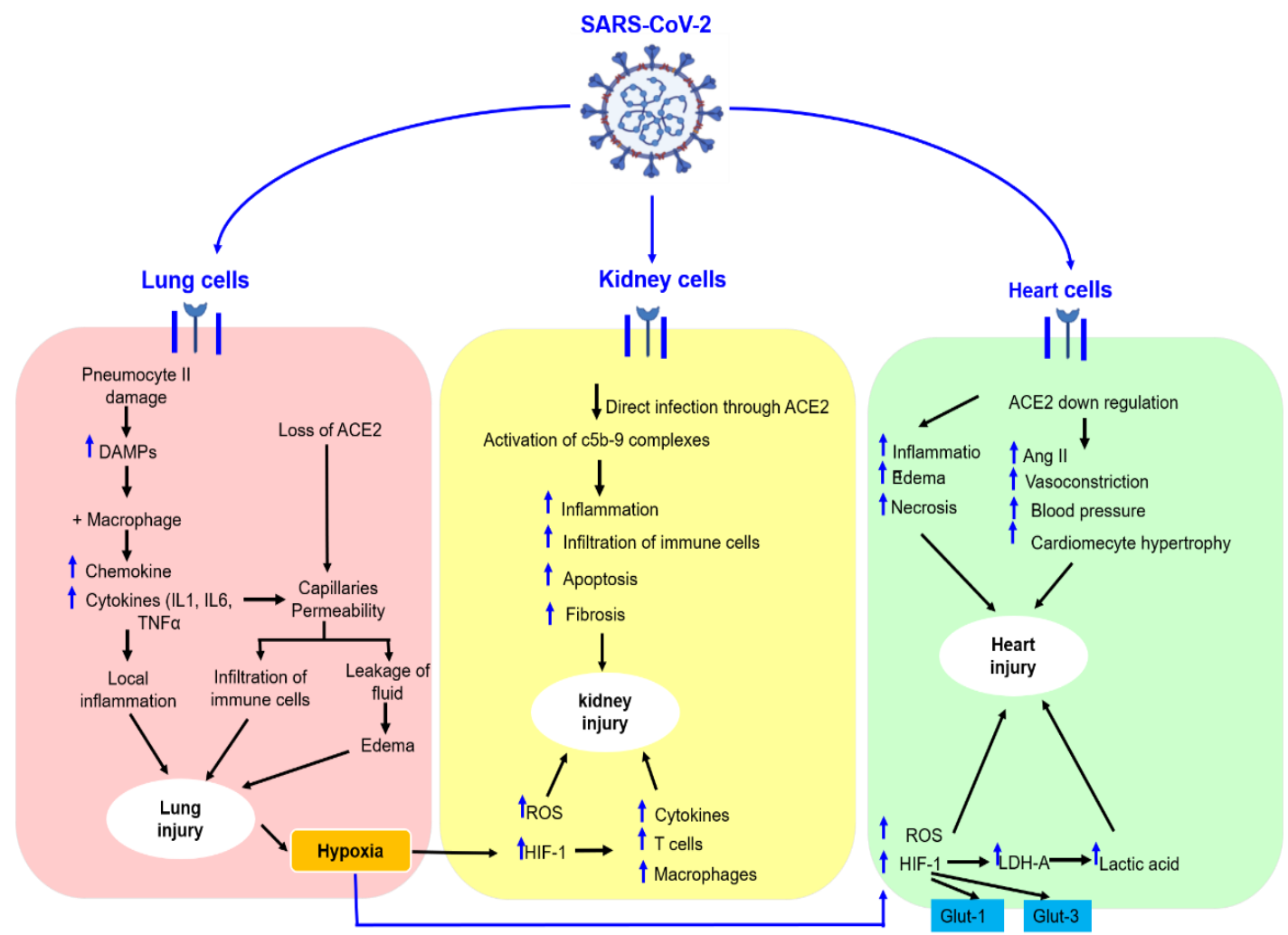

Figure 6. Physiopathology of COVID-19 on lung, kidney, and heart cells. The direct infection of lung cells increases DAMPs activated macrophages, which lead to the release of chemokines and cytokines, which induce local inflammation and capillaries permeability (increased by the loss of ACE2). Prolonged local inflammation, immune cell infiltration, and edema induce lung injury, which therefore decreases molecular oxygen exchange (hypoxia). In kidney cells, the penetration of SARS-CoV-2 activates the complement system, which induces inflammatory responses. This led to the infiltration of the immune system, which induces apoptosis and eventually fibrosis. Moreover, hypoxia conditions, induced by molecular oxygen exchange perturbation, increase ROS production, and activate HIF-1, which increases macrophages, $\mathrm{T}$ cells, and cytokines. These cellular and molecular consequences are responsible for kidney injury. In the heart, cell injury is induced by necrosis, cardiomyocyte hypertrophy, lactic acid, and ROS. Firstly, the virus induces inflammation, edema, and necrosis. It also increases cardiomyocyte hypertrophy via the activation of Ang II, vasoconstriction, and blood pressure. HIF-1 increases ROS production and reprogrammes energetic metabolic through the activation of LDH-A and lactic acid production.

\subsection{Pathophysiologyon kidney.}

A study conducted on 59 patients infected by SARS-CoV-2 showed that $63 \%$ exhibited proteinuria, which is considered an indication of renal impairment. Also, $19 \%$ of the patients had an increased level of plasma creatinine, and 27\% had increased urea nitrogen[59]. The elderly patients and cases with comorbidities such as hypertension and heart disease were 
reported to be more susceptible to renal failure [60]. This renal impairment was confirmed by the computerized tomography CT scan, which showed radiographic abnormalities of the kidneys in all patients (inflammation and edema occurring in the parenchyma) [59]. Using immunohistochemistry of SARS-CoV-2 nucleocapsid protein antigen in kidney specimens of six death cases, authors found that CoV-2 can be detected in distal convoluted renal tubules, proximal straight tubule cells, and absent in the glomerulus [60]. The authors suggested that renal impairment might be caused by SARS-CoV-2 entering the cell through ACE2 (highly expressed in the kidney) [59].

The expression of ACE2 in the kidney facilitates the virus entry to the cells, especially in renal tubular cells (the functional unit of the kidney) [61]. The injury of tubular cells might release pro-inflammatory cytokines such as IL2, IL7, IL10, GSCF, IP-10, MCP1 , MIP1A, TNF- $\alpha$ ) known as cytokines storm, which may lead to overactivation of the immune system [62]. Moreover, renal tubular cell injury could cause renal tubules atrophy, thereby aggravating renal interstitial fibrosis, secreting a variety of chemokines and growth factors into the stroma, promoting interstitial inflammatory cell infiltration, interstitial intrinsic cell proliferation, and extracellular matrix (ECM) accumulation [58].

In addition, kidney injury can be a result of the indirect effect of SARS-CoV-2. The injury of the lungs leads to hypoxia, and the kidney is one of the sense organs to this problem [63]. The deprivation of oxygen may cause HIF-1 (Hypoxia-inducible factor 1)protein activation [64] and ROS generation [65]. HIF-1 stimulates the synthesis of fibrous connective tissue and can interfere with the normal function of the kidney [64] as well as it enhances the effector $\mathrm{T}$ cell function, including the promotion of cytolytic activity and inflammatory cytokine production [66], while ROS destroy the molecular components of nephron inducing a cells damage and/or death [67]. Moreover, SARS-CoV-2 infection can induce acute tubular necrosis and ARF by triggering complement membrane-attack complex (C5b-9) deposition on tubules or glomeruli [60] (Figure 6).

\subsection{Pathophysiologyon heart.}

It was reported that SARS-CoV-2 might induce heart injury [59]. The imbalance of the renin-angiotensin system might contribute to this pathogenesis [59] - the loss of ACE2 caused by SARS-CoV-2 results in angiotensin II accumulation. The accumulation of angiotensin II triggers vasoconstriction, blood pressure, and cardiomyocyte hypertrophy [59]. In addition, the expression of ACE2 in the heart [61] can lead to an inflammatory storm after infection by SARS-CoV-2. This inflammatory storm aggravates heart injury noticed in COVID-19 patients by edema and degeneration and necrosis of cardiomyocytes [59]. Another mechanism that could cause heart injury is hypoxemia resulted from lung injury [59]. The hypoxemia caused by lung injury leads to ROS accumulation, an increase of lactic acid and other metabolites, and myocardial injury. Also, the lack of oxygen increases the heart rate, which can lead to heart injury [59] (Figure 6). The last reported raison of heart injury caused by SARS-CoV-2 is the emotional state of the patients. The anxiety and fear may increase the stress, which leads to the augmentation of catecholamine levels. This latter has been known to increase blood pressure, blood perfusion, and can lead to sudden cardiac death [59]. 


\subsection{Pathophysiologyon immune system.}

Huang et al. [68] reported the immunological state of 41 patients infected by SARSCoV-2. These patients included 13 with ICU cases and 28 non-ICU cases. They noticed that the patients infected with SARS-CoV-2 had increased amounts of IL1B, IFN- $\gamma$, IP10, and MCP1, and they suggested that this probably led to the activation of T-helper-1 (Th1) cell responses. In addition, they reported that the ICU cases had higher concentrations of GCSF, IP10, MCP1, MIP1A, and TNF $\alpha$ comparing with non-ICU cases [68]. The authors suggested that the cytokine storm was associated with disease severity. On the other hand, the patients infected with SARS-CoV-2 presented increased secretion of Th2 cytokines, such as IL4 and IL10, that lead to inflammation suppression [68], which is different from SARS-CoV infection. Another recent study reported a reduction of CD4+T, CD8+T, B cell, NK cell, especially CD4+T, and CD8+ in SARS-CoV-2 patients, and that was important in severe cases [69]. But this study has some limitations such as the sample size (123 patients) was relatively small, the humoral immunity level of the included patients was not monitored, and the lack of blank controls. It was reported that SARS-CoV-2 upregulates apoptosis, autophagy, and P53 pathways in peripheral blood mononuclear cells of COVID-19 patients [70] (Figure 7). Moreover, SARS-CoV-2 might affect $\mathrm{T}$ cells via $\mathrm{S}$ protein-mediated membrane fusion [71] (Figure 7). In fact, SARS-CoV-2 could infect T cell, but it could not replicate inside it, and then the viral RNA degraded [71]. Based on these data, further studies should be done in order to better understand the immunopathology of COVID-19. The most promising studies can be carried out from autopsy and biopsy [68].
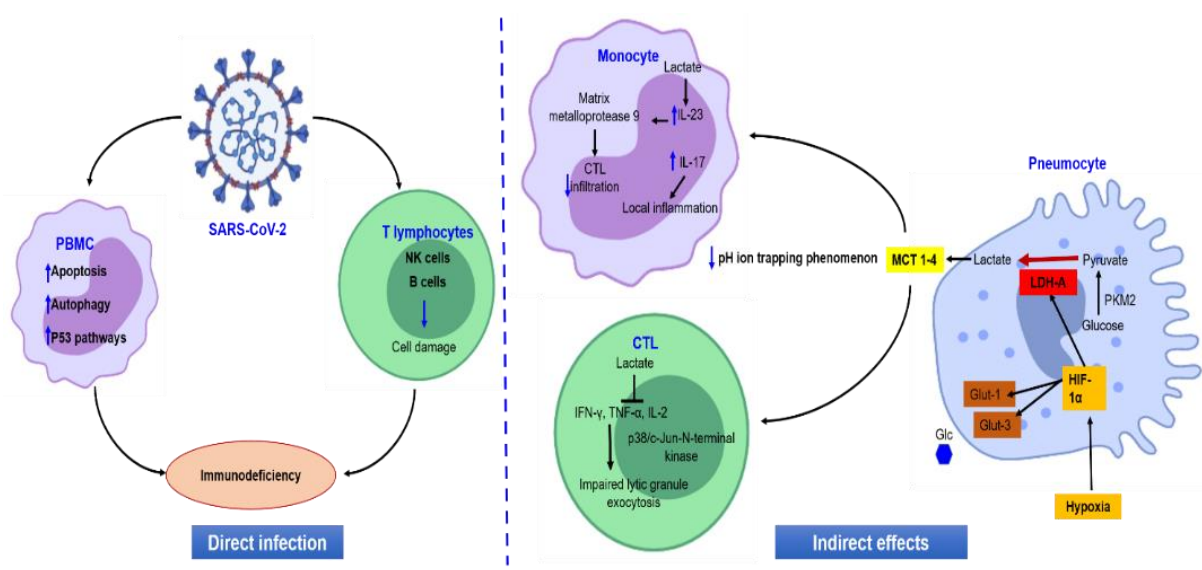

Figure 7. Physiopathology of COVID-19 on the immune system. SARS-CoV-2 can induce direct and direct effects on immune cells. In direct effects, the virus induces an increase of apoptosis, autophagy, and p53 pathways on PBMC, and cellular damage on lymphocyte cells such as NK and B cells. In indirect effects, hypoxia conditions in pneumocyte induce HIF-1 $\alpha$ production, which activates LDH-A responsible for lactate synthesis. This metabolite is transported to an extracellular medium, induce a change in $\mathrm{pH}$, and therefore deregulates drug transport. The accumulation of lactate in monocyte increased the secretion of IL-23, which induce the production of matrix metalloprotease 9 and therefore decreased CTL infiltration. Moreover, lactate inhibited INF- $\gamma$, TNF- $\alpha$, and IL-2 in CTL cells through p38/c-Jun-N-terminal pathway and led to impaired lytic granule exocytosis.

\subsection{Pathophysiologyon liver.}

COVID-19 patients were reported to have higher liver dysfunction, and liver injury is more prevalent in severe cases [62]. Some patients exhibited elevation of some hepatic enzymes such as aspartate aminotransferase and alanine aminotransferase [68, 72]. The data from previous studies carried out on SARS-CoV patients showed several pathologic effects 
detected in the liver tissue. In some cases, apparent dissociation of hepatocyte cords has been noticed as well as fatty degeneration and focal necrosis. In other cases, massive central necrosis was observed in hepatocytes. In addition, the vascular walls and circumference of small veins in the liver showed edema and infiltration of monocytes and lymphocytes [52]. The autopsy study also showed some degeneration of hepatocytes in the centrilobular zone and focal atrophy [53]. The mechanism of liver injury can include direct viral infection of hepatic cells, drug hepatotoxicity, immune-mediated inflammation caused by cytokine storms as well as pneumonia-associated hypoxia [62] (Figure 8).

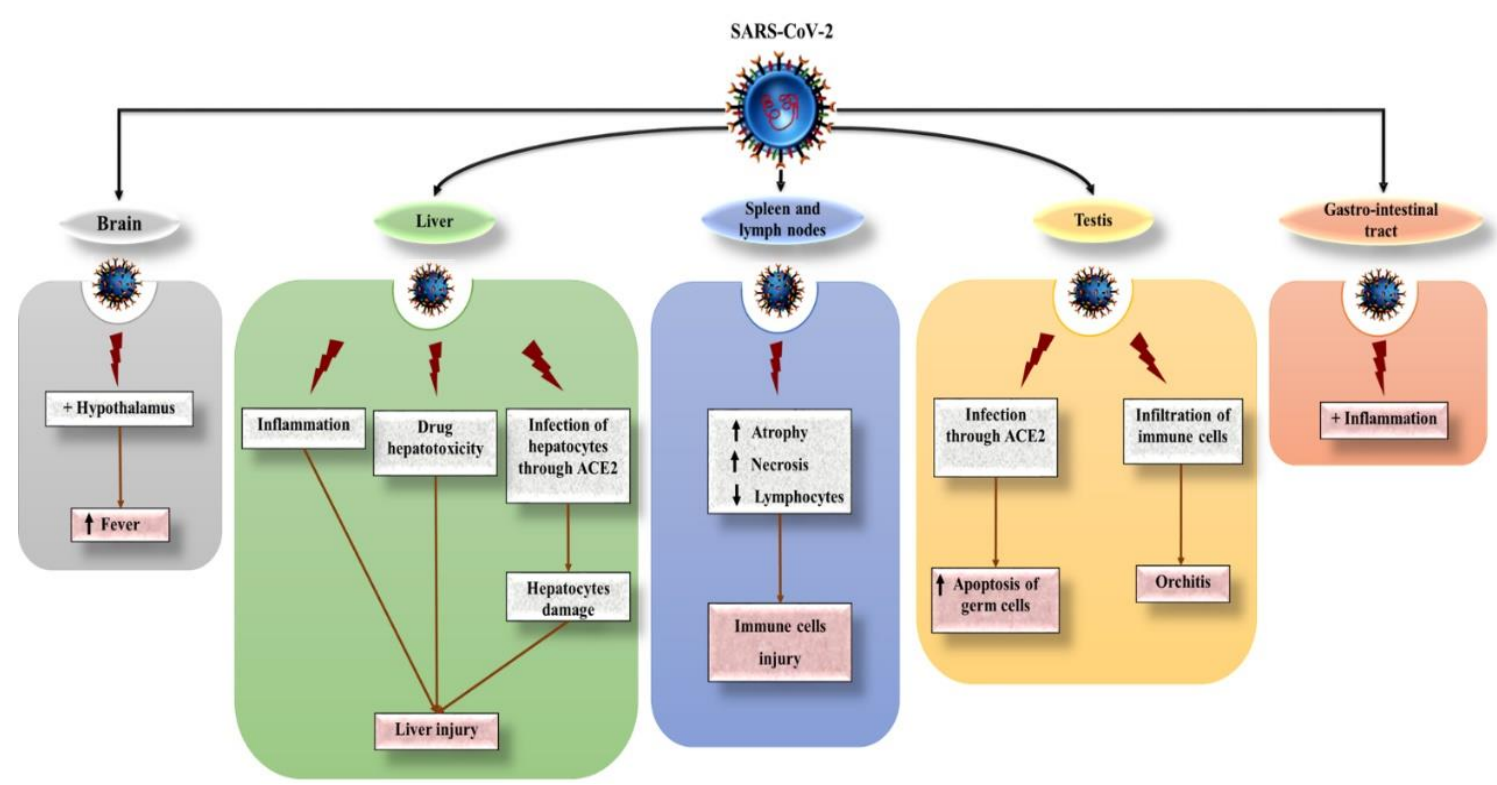

Figure 8. Pathophysiology of COVID-19 on brain, liver, testis, gastrointestinal tract, spleen, and lymph nodes.

\subsection{Pathophysiologyon gastrointestinal tract.}

It was reported that the patients of COVID-19 exhibited diarrhea, anorexia, and nausea $[73,74]$. Since the ACE2 receptor is also expressed in the intestine [75], there is a high probability that SARS-CoV-2 can attack the gastrointestinal tract. Using RT-PCR, SARSCoV-2 RNA was detected in the esophagus, stomach, duodenum, and rectum specimens of severe patients, and only on the duodenum of one of the four non-severe patients [73]. The patients of SARS-CoV showed mild inflammatory changes in the gastrointestinal tract, with depletions of the submucosa lymphoid tissues [53] (Figure 8). In addition, in situ hybridization showed that small and large intestines were infected by the virus. Gu et al. [53] suggested that SARS-CoV infects the gastrointestinal tract through the infected circulating immune cells because the virus was not found in the esophagus and stomach. While this way of infection might not be suggested for SARS-CoV-2 since the virus could not replicate in immune cells [71]. The gastrointestinal infection by SARS-CoV-2 should not be underestimated, and further investigations are necessary to better understand the mechanisms of this infection.

\subsection{Physiopathology on spleen and lymph nodes.}

Until now, there are no data about the pathogenesis of SARS-CoV-2 on spleen and lymph nodes. The results from autopsy studies on SARS-CoV showed several pathologies in the spleen and lymph nodes. The studies reported that the SARS-CoV patients presented prominent splenic atrophy $[52,53]$ associated with massive necrosis of lymphoid tissue in white pulp and marginal sinus [52]. In addition, a dilatation and congestion of vessels in 
pulmonary hilar and abdominal lymph nodes with loss of corticomedullary distinction were also observed [52]. Moreover, the marginal sinus and germinal centers disappeared in some lymph nodes, and many monocytes and plasmacytoid monocytes could be seen in the remaining lymphatic sinus. Localized necrosis was present, and there was apoptosis of lymphocytes in both the spleen and the lymph nodes [52, 53] (Figure 8).

\subsection{Pathophysiologyon brain.}

An autopsy study was carried out by Ding et al. [52] reported that two amongst three patients infected by SARS-CoV exhibited edema around the small veins in the brain,withinfiltration of the vascular walls by monocytes and lymphocytes. In addition, the authors noticed slight edema in brain tissue, with demyelination of some nerve fibres and focal neuronal degeneration [52]. Other studies [66,88] reported the presence of SARS sequences in the brain of SARS autopsies. These results were confirmed by three complementary methods, namely LM, EM, and RT-PCR. The sequences were detected mainly in neurons in the hypothalamus and cortex. The brain of some SARS-CoV patients exhibited edema and scattered degeneration of neurons [53]. The control (not infected persons) had not exhibited any pathologic changes, and the viral particles were absent in their brains. Xu et al. [88] also reported the revelation of neuron cell necrosis and broad hyperplasia of gliocytes. The scattered red degeneration of the neurons was explained by hypoxia and ischemia [53]. Using mice models, [77] have reported that the virus enters the brain primarily via the olfactory bulb, and the infection results in rapid transneuronal spread to connected areas of the brain. The authors suggested that the existence of the virus in neurons could be the cause of psychologic abnormalities observed in SARS-CoV patients in late-stage, which were attributed previously to negative social pressure during the epidemic [53].

\subsection{Pathophysiologyon bone marrow.}

Up to date, no study has been reported about the pathological effect of SARS-CoV-2 on human bone marrow. The data from SARS-CoV showed that the patients exhibited a decrease in bone marrow hematopoietic tissue, accompanied by a relative reduction in granulocyte megakaryocyte lineages and localized proliferation of polychromatophilic erythroblasts [52].

\subsection{Pathophysiologyon testis.}

Up to date, there is no study concerning the pathological effect of SARS-CoV-2 on human reproduction function. Xu et al. [78] investigated the effect of SARS-CoV on the testis. By histological observation, minimal peritubular fibrosis and vascular congestion were observed in the interstitial tissue of SARS-CoV patients. Also, extensive germ cell destruction was detected in all SARS-CoV patients tested. A thickens of the basement membrane, and peritubular fibrosis was observed. Leukocyte infiltration and vascular congestions were present in the interstitial tissue. Using the immunohistochemistry, an increase in CD3+ T lymphocytes and CD68+ macrophage was observed in SARS-CoV patients. Also, these cells were detected in the seminiferous tubules of these patients, which are normally absent in these tubules. Moreover, extensive immunoreaction of $\mathrm{IgG}$ was detected in the seminiferous epithelium, interstitium, some degenerated germ cells, and Sertoli cells. Also, an increased apoptotic spermatogenetic cell was observed in SARS-CoV patients. The degeneration and the 
destruction of the germ cell were explained by the increase in the body temperature caused by SARS-CoV, and also the treatment by steroids, which could affect spermatogenesis [78]. Moreover, ACE2 is highly expressed in human testis [61]. This suggests that SARS-CoVcan directly infect the testis. Moreover, the infiltration of leukocytes could affect Leydig cell function, and as a consequence, the production of testosterone will be affected. This infection could lead to the activation of the autoimmune response on the tubule [78]. Further, investigation of SARS-CoV-2 pathogenesis on testis is necessary.

\section{Diagnosis of COVID-19}

\subsection{Molecular analysis.}

Real-time PCR (RT-PCR) techniques offer the advantages of high reproducibility and sensitivity [79]. RT-PCR systems rely on the detection and quantification of a fluorescent emitter during the amplification process, and the increase in the fluorescent emission signal is directly related to the number of amplicons produced during the reaction.

Reverse transcriptase PCR is used to detect RNA, as the RNA is reverse transcribed to DNA source. This quantitative test has been commonly used for the detection of viruses causing respiratory secretions and for the final pathogenic diagnostics of COVID-19. It involves the use of an enzyme, usually Taq polymerase, which amplifies a short specific part, and probes that allow the quantification of PCR products.

Since the onset of the disease, WHO has disseminated a protocol established by the Pasteur Institute of Paris, then other protocols have been established by Corman et al. [9]. These protocols designate a set of primers that target different regions of the SARS-CoV-2 genome (Table 1). However, the sensitivity and the specificity of this type of test remain relatively low compared to metagenomic PCR tests that have not yet been used [80].

Table 1. Primers and probes of real-time RT-PCR are designed to detect novel coronavirus 2019.

\begin{tabular}{|c|c|c|c|c|}
\hline \multicolumn{2}{|l|}{ Gene } & Oligonucleotide & Sequence & Reference \\
\hline \multirow[t]{10}{*}{ RdRPgene } & \multirow[t]{3}{*}{$\begin{array}{l}\text { nCoV- } \\
\text { IP2 }\end{array}$} & $\begin{array}{l}\text { nCoV_IP2-12696b Probe } \\
(+)\end{array}$ & $\begin{array}{l}\text { HEX- } \\
\text { AGATGTCTTGTGCTGCCGGTA } \\
\text { BHQ-1 }\end{array}$ & \multirow[t]{3}{*}[81]{} \\
\hline & & nCoV_IP2-12669 Fw & ATGAGCTTAGTCCTGTTG & \\
\hline & & nCoV_IP2-12759 Rv & CTCCCTTTGTTGTGTTGT & \\
\hline & \multirow[t]{3}{*}{$\begin{array}{l}\mathrm{nCoV}- \\
\mathrm{IP} 4\end{array}$} & $\begin{array}{ll}\text { nCoV_IP4-14084 Probe } \\
(+)\end{array}$ & $\begin{array}{l}\text { FAM } \\
\text { TCATACAAACCACGCCAGG } \\
\text { BHQ-1 }\end{array}$ & \multirow[t]{3}{*}[81]{} \\
\hline & & nCoV_IP4-14059Fw & GGTAACTGGTATGATTTCG & \\
\hline & & nCoV_IP4-14146Rv & CTGGTCAAGGTTAATATAGG & \\
\hline & \multicolumn{2}{|c|}{$\begin{array}{l}\text { RdRP_SARSr-P1 } \\
\text { Probe } 1\end{array}$} & $\begin{array}{l}\text { FAM-CCAGGTGGWACRTCATCMGGTGATGC- } \\
\text { BBQ }\end{array}$ & \multirow{4}{*}{ [9] } \\
\hline & \multicolumn{2}{|c|}{$\begin{array}{l}\text { RdRp_SARSr-P2 } \\
\text { Probe } 2\end{array}$} & $\begin{array}{l}\text { FAM-CAGGTGGAACCTCATCAGGAGATGC- } \\
\text { BBQ }\end{array}$ & \\
\hline & \multicolumn{2}{|c|}{ RdRp_SARSr-Fw } & GTGARATGGTCATGTGTGGCGG & \\
\hline & \multicolumn{2}{|c|}{ RdRp_SARSr-Rv } & CARATGTTAAASACACTATTAGCATA & \\
\hline \multirow[t]{3}{*}{ E gene } & \multicolumn{2}{|c|}{$\begin{array}{l}\text { E_Sarbeco_P1 } \\
\text { Probe }\end{array}$} & $\begin{array}{l}\text { FAM-ACACTAGCCATCCTTACTGCGCTTCG- } \\
\text { BBQ }\end{array}$ & \multirow{3}{*}{ [9] } \\
\hline & \multicolumn{2}{|c|}{ E_Sarbeco_FW } & ACAGGTACGTTAATAGTTAATAGCGT & \\
\hline & \multicolumn{2}{|c|}{ E_Sarbeco_Rv } & ATATTGCAGCAGTACGCACACA & \\
\hline \multirow[t]{3}{*}{ N gene } & \multicolumn{2}{|c|}{$\begin{array}{l}\text { N_Sarbeco_P } \\
\text { Probe }\end{array}$} & $\begin{array}{l}\text { FAM-ACTTCCTCAAGGAACAACATTGCCA- } \\
\text { BBQ }\end{array}$ & \multirow{3}{*}{ [9] } \\
\hline & \multicolumn{2}{|c|}{ N_Sarbeco_Fw } & CACATTGGCACCCGCAATC & \\
\hline & \multicolumn{2}{|c|}{ N Sarbeco Rv } & GAGGAACGAGAAGAGGCTTG & \\
\hline
\end{tabular}




\subsection{Serological tests.}

\subsubsection{Rapid IgM-IgG combined antibody test.}

Rapid test for SARS-CoV-2 diagnosis is based on the principle of lateral flow immunochromatography and allows the qualitative detection of antibodies produced by the patient. In fact, over an infection, the immune system produces the immunoglobulins IgM and $\mathrm{IgG}$ to protect the body against the virus. The presence of these two types of antibody isotypes is indicated by the presence of a band corresponding to its immunoglobulin at the level of the cassette. The sample is considered positive if $\operatorname{IgM}$, IgG or IgM, and IgG antibodies are present. The cartridge is composed of a sample pad, conjugate pad, nitrocellulose membrane, and absorption pad. After depositing the sample and buffer, the combined sample flows to the sampling buffer. Thereafter, lateral flow by capillary action will move the sample across the test (Figure 9).

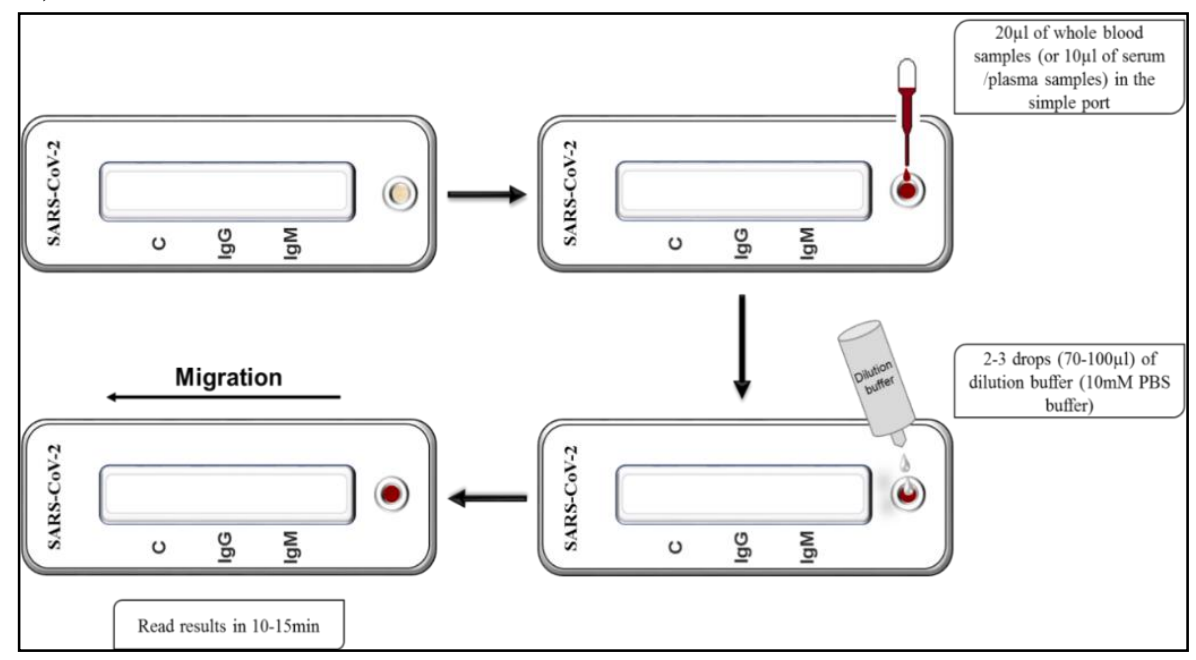

Figure 9. Steps to perform the SARS-CoV-2 rapid diagnostic test.

After deposition, the sample reacts with the conjugation buffer that contains the SARSCoV-2 antigen conjugated to gold nanoparticles (AuNP) colloid. Every antibody in the sample that recognizes the SARS-CoV-2 antigen binds to the corresponding Antigen-AuNP complex. The sample-conjugate complex then migrates by capillarity and lateral flow to the nitrocellulose membrane and comes in contact with the three test lines: $\operatorname{IgM}, \operatorname{IgG}$, and $\mathrm{C}$ (control) (Figure 10).

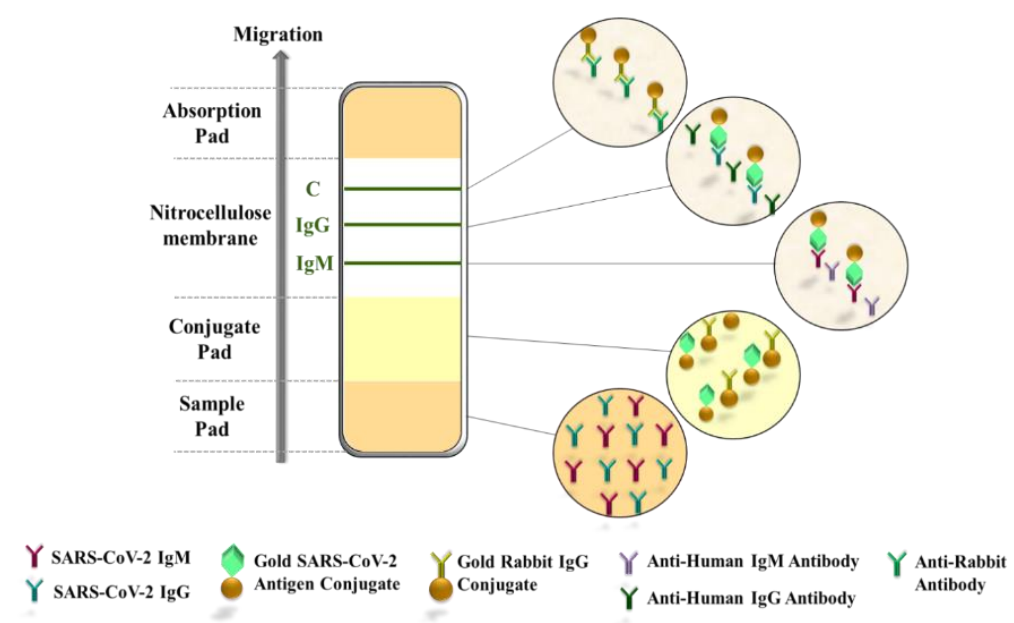

Figure 10. Schematic illustration of the SARS-CoV-2 lateral flow test. 
The IgM line comes first and contains an immobilized antibody that allows the detection of human $\operatorname{IgM}$ - followed by the IgG line that contains an immobilized antibody, which recognizes human IgG. The last line encountered by the sample is the control line that contains an immobilized antibody, which recognizes rabbit IgG. The coloring of the IgM and IgG lines will be produced by the human antibody (IgM or IgG)/SARS-CoV-2 antigen/gold nanoparticles complex.

IgM antibodies are the first antibodies to appear (about a week after the initial infection). Regarding IgG, they rather serve as an indicator of a previous infection since they appear later (generally within 14 days of infection). These IgG antibodies can bind to the substance that caused the immune response because of their higher affinity for the target antigen.

The sample is considered positive if $\operatorname{IgM}$ or $\operatorname{IgG}$ is present. However, both $\operatorname{IgM}$ and $\operatorname{IgG}$ antibodies can coexist in a sample (Figure 11). This implies that the conversion of a mainly $\operatorname{IgM}$ humoral response to $\mathrm{IgG}$ is in progress.

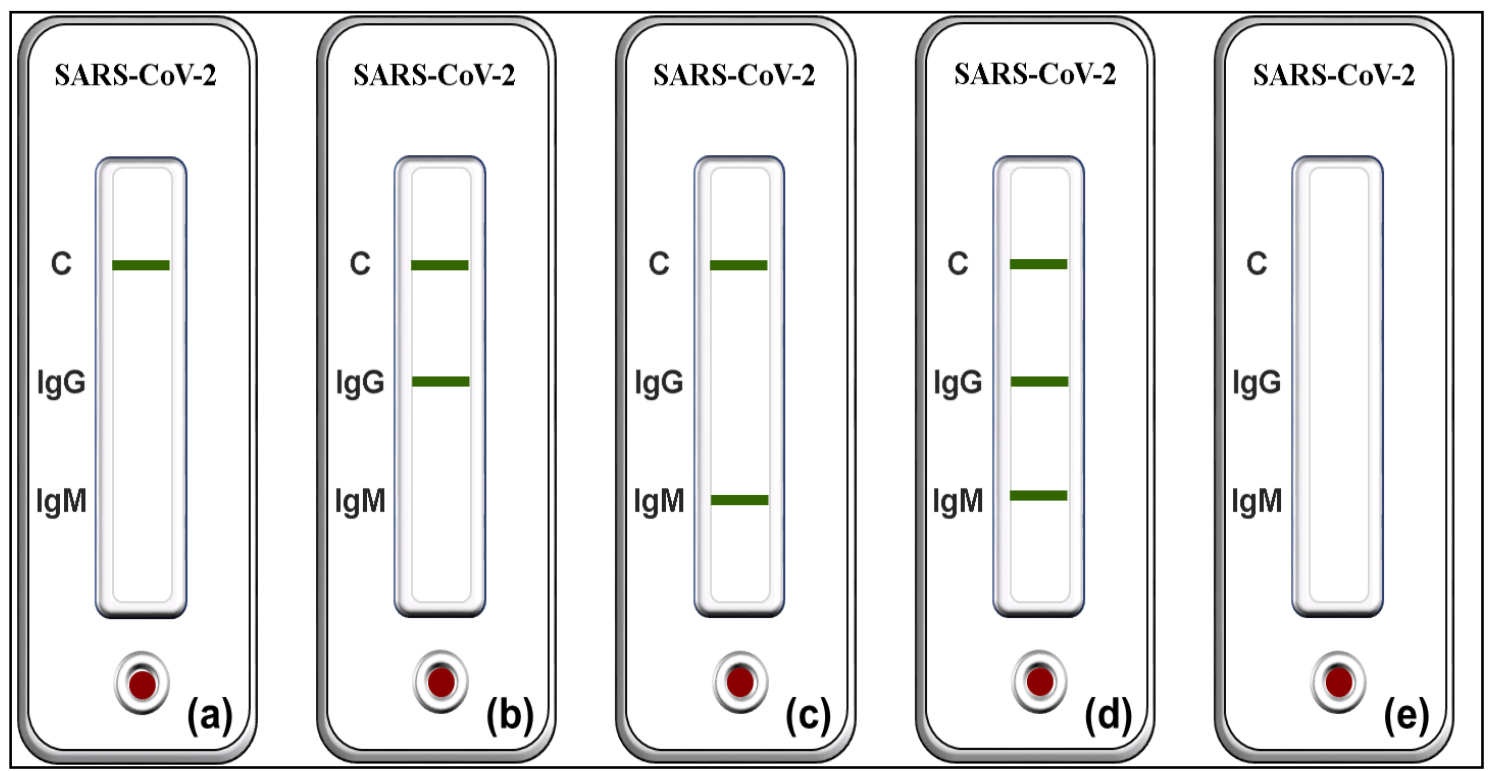

Figure 11. Schematic illustration of different rapid test results. (a): Negative result; (b): Previous SARS-CoV-2 infection; (c): Recent SARS-CoV-2 infection; (d): Recent SARS-CoV-2 infection; (e): Invalid result.

\subsubsection{ELISA.}

ELISA test is used more frequently to measure specific $\operatorname{IgM}$ and $\mathrm{IgG}$ antibodies. It can detect both antibodies and antigens in a sample. The principle of this technique makes it possible to visualize an antigen-antibody reaction by a colored reaction produced by the action on a substrate of an enzyme previously fixed to the antibody.

Generally, serological tests on anti-coronavirus antibodies by ELISA (Enzyme-Linked Immunosorbent Assays) remain the final method that can be used for the detection of antibodies produced as a response against infections. However, their use is of great interest. Indeed, these serological tests allow first of all to qualitatively and quantitatively study the immune responses against SARS-CoV-2. They also make it possible to determine the precise rate of infection in an area and therefore determine the precise rate of mortality by infection. Finally, serological tests will determine who is immunized and who is not. The antibodies that can be used in an ELISA detection kit concerning SARS-CoV-2 include spike antibody, envelope antibody, membrane antibody, or nucleocapsid antibody. 


\subsubsection{Chest X-ray and CT scan.}

Other diagnostic techniques for COVID-19 include chest X-rays and chest CT scans. These detection techniques reveal the presence of SARS-CoV-2 in patients with negative RTPCR results despite the presence of the symptoms associated with the disease. Both of these methods can reveal abnormalities indicative of lung disease.

The imaging study, chest X-ray, is the most commonly ordered study for patients with respiratory conditions. However, it can be read as normal in patients in the early stages of infection. Regarding the CT scan, it is a more effective technique than a chest X-ray for the early detection of the disease. This specialized imaging study uses X-rays to create 3D images of the chest.

Specific symptoms associated with the presence of SARS-CoV-2 include uneven or diffuse asymmetric opacities caused by increased pulmonary opacity through which the vessels and bronchial structures are still visible. In addition, interstitial thickening or partial collapse of the pulmonary alveoli may also be observed [82].

\section{Conclusion}

The epidemy of COVID-19 caused several pathophysiological dysfunctions that affected several organs. The mechanistic pathways implicated in these dysfunctions were not molecularly understood; however, it seems that excessive inflammatory response is responsible for these different pathophysiologies. Moreover, the understanding of the interactions between SARS-CoV-2 and the immune system allowed the establishment of some rapid serological tests based on antibody secretion.

\section{Funding}

This research received no external funding.

\section{Acknowledgments}

This research has no acknowledgment.

\section{Conflicts of Interest}

The authors declare no conflict of interest.

\section{References}

1. Liu, C.; Zhou, Q.; Li, Y.; Garner, L.V.; Watkins, S.P.; Carter, L.J.; Smoot, J.; Gregg, A.C.; Daniels, A.D.; Jervey, S.; Albaiu, D. Research and Development on Therapeutic Agents and Vaccines for COVID-19 and Related Human Coronavirus Diseases. ACS Cent. Sci 2020, 6, 315-331, https://doi.org/10.1021/acscentsci.0c00272.

2. Nadjib, B.M. Effective Antiviral Activity of Essential Oils and Their Characteristic Terpenes against Coronaviruses: An Update. J. Pharmacol. Clin. Toxicol 2020, 9.

3. Fischer, A.; Sellner, M.; Neranjan, S.; Lill, M. A. Inhibitors for Novel Coronavirus Protease Identified by Virtual Screening of 687 Million Compounds. ChemRxiv 2020, 21.

4. Phan, L.T.; Nguyen, T.V.; Luong, Q.C.; Nguyen, T.V.; Nguyen, H.T.; Le, H.Q.; Nguyen, T.T.; Cao, T.M.; Pham, Q.D. Importation and Human-to-Human Transmission of a Novel Coronavirus in Vietnam. N. Engl. J. Med 2020, 382, 872-874.

5. Shereen, M.A.; Khan, S.; Kazmi, A.; Bashir, N.; Siddique, R. COVID-19 Infection: Origin, Transmission, and Characteristics of Human Coronaviruses. J Adv Res 2020, 24, 91-98, https://doi.org/10.1016/j.jare.2020.03.005. 
6. Hong, H.; Wang, Y.; Chung, H.-T.; Chen, C.-J. Clinical Characteristics of Novel Coronavirus Disease 2019 (COVID-19) in Newborns, Infants and Children. Pediatr. Neonatol 2020, 0 , https://doi.org/10.1016/j.pedneo.2020.03.001.

7. Rothan, H.A.; Byrareddy, S.N. The Epidemiology and Pathogenesis of Coronavirus Disease (COVID-19) Outbreak. J Autoimmun 2020, 109, https://doi.org/10.1016/j.jaut.2020.102433.

8. Yang, Y.; Islam, M. S.; Wang, J.; Li, Y.; Chen, X. Traditional Chinese Medicine in the Treatment of Patients Infected with 2019-New Coronavirus (SARS-CoV-2): A Review and Perspective. Int J Biol Sci 2020, 16 (10), 1708-1717. https://doi.org/10.7150/ijbs.45538.

9. Corman, V.M.; Landt, O.; Kaiser, M.; Molenkamp, R.; Meijer, A.; Chu, D.K.; Bleicker, T.; Brünink, S.; Schneider, J.; Schmidt, M.L.; Mulders, D.G.; Haagmans, B.L.; van der Veer, B.; van den Brink, S.; Wijsman, L.; Goderski, G.; Romette, J.-L.; Ellis, J.; Zambon, M.; Peiris, M.; Goossens, H.; Reusken, C.; Koopmans, M.P.; Drosten, C. Detection of 2019 Novel Coronavirus (2019-NCoV) by Real-Time RT-PCR. Eurosurveillance 2020, 25, https://doi.org/10.2807/1560-7917.ES.2020.25.3.2000045.

10. Zhang, L.; Liu, Y. Potential Interventions for Novel Coronavirus in China: A Systematic Review $J$ Med Virol 2020, 92, 479-490, https://doi.org/10.1002/jmv.25707.

11. Walls, A.C.; Park, Y.-J.; Tortorici, M.A.; Wall, A.; McGuire, A.T.; Veesler, D. Structure, Function, and Antigenicity of the SARS-CoV-2 Spike Glycoprotein. Cell 2020, 181, 281-292.e6, https://doi.org/10.1016/j.cell.2020.02.058.

12. Cascella, M.; Rajnik, M.; Cuomo, A.; Dulebohn, S.C.; Di Napoli, R. Features, Evaluation and Treatment Coronavirus (COVID-19). In: StatPearls. StatPearls Publishing: Treasure Island (FL), 2020.

13. Farsani, S.M.J.; Dijkman, R.; Jebbink, M.F.; Goossens, H.; Ieven, M.; Deijs, M.; Molenkamp, R.; van der Hoek, L. The First Complete Genome Sequences of Clinical Isolates of Human Coronavirus 229E. Virus Genes 2012, 45, 433-439, https://doi.org/10.1007/s11262-012-0807-9.

14. Boursnell, M.E.G.; Brown, T.D.K.; Foulds, I.J.; Green, P.F.; Tomley, F.M.; Binns, M.M. Completion of the Sequence of the Genome of the Coronavirus Avian Infectious Bronchitis Virus. J Gen Virol 1987, 68, 57-77, https://doi.org/10.1099/0022-1317-68-1-57.

15. Abro, S.H.; Renström, L.H.M.; Ullman, K.; Belák, S.; Baule, C. Characterization and Analysis of the FullLength Genome of a Strain of the European QX-like Genotype of Infectious Bronchitis Virus. Arch Virol 2012, 157, 1211-1215, https://doi.org/10.1007/s00705-012-1284-0.

16. Ammayappan, A.; Upadhyay, C.; Gelb, J.; Vakharia, V.N. Complete Genomic Sequence Analysis of Infectious Bronchitis Virus Ark DPI Strain and Its Evolution by Recombination. Virol J 2008, 5, https://doi.org/10.1186/1743-422X-5-157.

17. Zhang, Y.; Wang, H.-N.; Wang, T.; Fan, W.-Q.; Zhang, A.-Y.; Wei, K.; Tian, G.-B.; Yang, X. Complete Genome Sequence and Recombination Analysis of Infectious Bronchitis Virus Attenuated Vaccine Strain H120. Virus Genes 2010, 41, 377-388, https://doi.org/10.1007/s11262-010-0517-0.

18. Srinivasan, S.; Cui, H.; Gao, Z.; Liu, M.; Lu, S.; Mkandawire, W.; Narykov, O.; Sun, M.; Korkin, D. Structural Genomics of SARS-CoV-2 Indicates Evolutionary Conserved Functional Regions of Viral Proteins. Viruses 2020, 12, https://doi.org/10.3390/v12040360.

19. Belouzard, S.; Millet, J.K.; Licitra, B.N.; Whittaker, G.R. Mechanisms of Coronavirus Cell Entry Mediated by the Viral Spike Protein. Viruses 2012, 4, 1011-1033, https://doi.org/10.3390/v4061011.

20. Bonnin, A. Caractérisation de la protéine $S$ du coronavirus humain 229E. PhdThesis, Université du Droit et de la Santé - Lille II, 2018.

21. Promkuntod, N.; van Eijndhoven, R.E.W.; de Vrieze, G.; Gröne, A.; Verheije, M.H. Mapping of the Receptor-Binding Domain and Amino Acids Critical for Attachment in the Spike Protein of Avian Coronavirus Infectious Bronchitis Virus. Virology 2014, 448, 26-32, https://doi.org/10.1016/j.virol.2013.09.018.

22. Kant, A.; Koch, G.; van Roozelaar, D.J.; Kusters, J.G.; Poelwijk, F.A.J.; van der Zeijst, B.A.M. Location of Antigenic Sites Defined by Neutralizing Monoclonal Antibodies on the S1 Avian Infectious Bronchitis Virus Glycopolypeptide. J Gen Virol 1992, 73, 591-596, https://doi.org/10.1099/0022-1317-73-3-591

23. Narayanan, K.; Chen, C.-J.; Maeda, J.; Makino, S. Nucleocapsid-Independent Specific Viral RNA Packaging via Viral Envelope Protein and Viral RNA Signal. J Virol 2003, 77, 2922-2927, https://doi.org/10.1128/JVI.77.5.2922-2927.2003.

24. Pfefferle, S.; Schöpf, J.; Kögl, M.; Friedel, C.C.; Müller, M.A.; Carbajo-Lozoya, J.; Stellberger, T.; von Dall'Armi, E.; Herzog, P.; Kallies, S.; Niemeyer, D.; Ditt, V.; Kuri, T.; Züst, R.; Pumpor, K.; Hilgenfeld, R.; Schwarz, F.; Zimmer, R.; Steffen, I.; Weber, F.; Thiel, V.; Herrler, G.; Thiel, H.-J.; Schwegmann-Weßels, C.; Pöhlmann, S.; Haas, J.; Drosten, C.; von Brunn, A. The SARS-Coronavirus-Host Interactome: Identification of Cyclophilins as Target for Pan-Coronavirus Inhibitors. PLoS Pathog 2011, 7, https://doi.org/10.1371/journal.ppat.1002331.

25. Liu, S.; Xiao, G.; Chen, Y.; He, Y.; Niu, J.; Escalante, C.R.; Xiong, H.; Farmar, J.; Debnath, A.K.; Tien, P.; Jiang, S. Interaction between Heptad Repeat 1 and 2 Regions in Spike Protein of SARS-Associated Coronavirus: Implications for Virus Fusogenic Mechanism and Identification of Fusion Inhibitors. The Lancet 2004, 363, 938-947, https://doi.org/10.1016/S0140-6736(04)15788-7. 
26. Glowacka, I.; Bertram, S.; Müller, M.A.; Allen, P.; Soilleux, E.; Pfefferle, S.; Steffen, I.; Tsegaye, T. S.; He, Y.; Gnirss, K.; Niemeyer, D.; Schneider, H.; Drosten, C.; Pöhlmann, S. Evidence That TMPRSS2 Activates the Severe Acute Respiratory Syndrome Coronavirus Spike Protein for Membrane Fusion and Reduces Viral Control by the Humoral Immune Response. J Virol 2011, 85, 4122-4134, https://doi.org/10.1128/JVI.02232-10.

27. Li, W.; Moore, M.J.; Vasilieva, N.; Sui, J.; Wong, S.K.; Berne, M.A.; Somasundaran, M.; Sullivan, J.L.; Luzuriaga, K.; Greenough, T.C.; Choe, H.; Farzan, M. Angiotensin-Converting Enzyme 2 Is a Functional Receptor for the SARS Coronavirus. Nature 2003, 426, 450-454, https://doi.org/10.1038/nature02145.

28. Matsuyama, S.; Nagata, N.; Shirato, K.; Kawase, M.; Takeda, M.; Taguchi, F. Efficient Activation of the Severe Acute Respiratory Syndrome Coronavirus Spike Protein by the Transmembrane Protease TMPRSS2. J Virol 2010, 84, 12658-12664, https://doi.org/10.1128/JVI.01542-10.

29. Simmons, G.; Gosalia, D.N.; Rennekamp, A.J.; Reeves, J.D.; Diamond, S.L.; Bates, P. Inhibitors of Cathepsin L Prevent Severe Acute Respiratory Syndrome Coronavirus Entry. Proc Natl Acad Sci 2005, 102, 11876-11881, https://doi.org/10.1073/pnas.0505577102.

30. Shirato, K.; Kawase, M.; Matsuyama, S. Wild-Type Human Coronaviruses Prefer Cell-Surface TMPRSS2 to Endosomal Cathepsins for Cell Entry. Virology 2018, 517, 9-15, https://doi.org/10.1016/j.virol.2017.11.012.

31. Fehr, A.R.; Perlman, S. Coronaviruses: An Overview of Their Replication and Pathogenesis. In: Coronaviruses: Methods and Protocols. Maier, H.J.; Bickerton, E.; Britton, P. Eds.; Methods in Molecular Biology; Springer: New York NY 2015; pp 1-23, https://doi.org/10.1007/978-1-4939-2438-7_1.

32. Abdel-Moneim, A.S. Coronaviridae: Infectious Bronchitis Virus. In: Emerging and Re-emerging Infectious Diseases of Livestock. Bayry, J. Ed.; Springer International Publishing: Cham 2017; pp 133-166, https://doi.org/10.1007/978-3-319-47426-7_5.

33. Raamsman, M.J.B.; Locker, J.K.; Hooge, A.de; Vries, A.A.F.de; Griffiths, G.; Vennema, H.; Rottier, P.J.M. Characterization of the Coronavirus Mouse Hepatitis Virus Strain A59 Small Membrane Protein E. J Virol 2000, 74, 2333-2342, https://doi.org/10.1128/JVI.74.5.2333-2342.2000.

34. Ujike, M.; Taguchi, F. Incorporation of Spike and Membrane Glycoproteins into Coronavirus Virions. Viruses 2015, 7, 1700-1725, https://doi.org/10.3390/v7041700.

35. Li, P.; Fu, J.-B.; Li, K.-F.; Chen, Y.; Wang, H.-L.; Liu, L.-J.; Liu, J.-N.; Zhang, Y.-L.; Liu, S.-L.; Tang, A.; Tong, Z.-D.; Yan, J.-B. Transmission of COVID-19 in the Terminal Stage of Incubation Period: A Familial Cluster. Int J Infect. Dis 2020, https://doi.org/10.1016/j.ijid.2020.03.027.

36. Shim, E.; Tariq, A.; Choi, W.; Lee, Y.; Chowell, G. Transmission Potential and Severity of COVID-19 in South Korea. Int J Infect Dis 2020, 93, 339-344, https://doi.org/10.1016/j.ijid.2020.03.031.

37. Yen, M.-Y.; Schwartz, J.; Chen, S.-Y.; King, C.-C.; Yang, G.-Y.; Hsueh, P.-R. Interrupting COVID-19 Transmission by Implementing Enhanced Traffic Control Bundling: Implications for Global Prevention and Control Efforts. J. Microbiol Immunol Infect 2020, 53, 377-380, https://doi.org/10.1016/j.jmii.2020.03.011.

38. Booth, T.F.; Kournikakis, B.; Bastien, N.; Ho, J.; Kobasa, D.; Stadnyk, L.; Li, Y.; Spence, M.; Paton, S.; Henry, B.; Mederski, B.; White, D.; Low, D.E.; McGeer, A.; Simor, A.; Vearncombe, M.; Downey, J.; Jamieson, F.B.; Tang, P.; Plummer, F. Detection of Airborne Severe Acute Respiratory Syndrome (SARS) Coronavirus and Environmental Contamination in SARS Outbreak Units. J Infect Dis 2005, 191, 14721477, https://doi.org/10.1086/429634.

39. Gan, W.H.; Lim, W.J.; Koh, D. Preventing Intra-Hospital Infection and Transmission of COVID-19 in Healthcare Workers. Saf Health Work 2020, 11, 241-243, https://doi.org/10.1016/j.shaw.2020.03.001.

40. Peeri, N.C.; Shrestha, N.; Rahman, M.S.; Zaki, R.; Tan, Z.; Bibi, S.; Baghbanzadeh, M.; Aghamohammadi, N.; Zhang, W.; Haque, U. The SARS, MERS and Novel Coronavirus (COVID-19) Epidemics, the Newest and Biggest Global Health Threats: What Lessons Have We Learned? Int J Epidemiol 2020, 49, 717-726, https://doi.org/10.1093/ije/dyaa033.

41. Tian, S.; Hu, N.; Lou, J.; Chen, K.; Kang, X.; Xiang, Z.; Chen, H.; Wang, D.; Liu, N.; Liu, D.; Chen, G.; Zhang, Y.; Li, D.; Li, J.; Lian, H.; Niu, S.; Zhang, L.; Zhang, J. Characteristics of COVID-19 Infection in Beijing. J Infect 2020, 80, 401-406, https://doi.org/10.1016/j.jinf.2020.02.018.

42. Kucharski, A.J.; Russell, T.W.; Diamond, C.; Liu, Y.; Edmunds, J.; Funk, S.; Eggo, R.M.; Sun, F.; Jit, M.; Munday, J.D.; Davies, N.; Gimma, A.; Zandvoort, K.van; Gibbs, H.; Hellewell, J.; Jarvis, C.I.; Clifford, S.; Quilty, B.J.; Bosse, N.I.; Abbott, S.; Klepac, P.; Flasche, S. Early Dynamics of Transmission and Control of COVID-19: A Mathematical Modelling Study. Lancet Infect Dis 2020, 80, 401-406, https://doi.org/10.1016/S1473-3099(20)30144-4.

43. Kwatra, S.G.; Sweren, R.J.; Grossberg, A.L. Dermatology Practices as Vectors for COVID-19 Transmission: A Call for Immediate Cessation of Non-Emergent Dermatology Visits. J Am Acad Dermatol 2020, 82, 179180, https://doi.org/10.1016/j.jaad.2020.03.037.

44. Wang, L.; Wang, Y.; Ye, D.; Liu, Q. A Review of the 2019 Novel Coronavirus (COVID-19) Based on Current Evidence. Int J Antimicrob Agents 2020, 55, https://doi.org/10.1016/j.ijantimicag.2020.105948.

45. Hsih, W.-H.; Cheng, M.-Y.; Ho, M.-W.; Chou, C.-H.; Lin, P.-C.; Chi, C.-Y.; Liao, W.-C.; Chen, C.-Y.; Leong, L.-Y.; Tien, N.; Lai, H.-C.; Lai, Y.-C.; Lu, M.-C. Featuring COVID-19 Cases via Screening 
Symptomatic Patients with Epidemiologic Link during Flu Season in a Medical Center of Central Taiwan. J Microbiol Immunol Infect 2020, 53, 459-466, https://doi.org/10.1016/j.jmii.2020.03.008.

46. Sohrabi, C.; Alsafi, Z.; O’Neill, N.; Khan, M.; Kerwan, A.; Al-Jabir, A.; Iosifidis, C.; Agha, R. World Health Organization Declares Global Emergency: A Review of the 2019 Novel Coronavirus (COVID-19). Int J Surg Lond Engl 2020, 76, 71-76, https://doi.org/10.1016/j.ijsu.2020.02.034.

47. Chen, H.; Guo, J.; Wang, C.; Luo, F.; Yu, X.; Zhang, W.; Li, J.; Zhao, D.; Xu, D.; Gong, Q.; Liao, J.; Yang, H.; Hou, W.; Zhang, Y. Clinical Characteristics and Intrauterine Vertical Transmission Potential of COVID19 Infection in Nine Pregnant Women: A Retrospective Review of Medical Records. The Lancet 2020, 395, 809-815, https://doi.org/10.1016/S0140-6736(20)30360-3.

48. Yang, W.; Cao, Q.; Qin, L.; Wang, X.; Cheng, Z.; Pan, A.; Dai, J.; Sun, Q.; Zhao, F.; Qu, J.; Yan, F. Clinical Characteristics and Imaging Manifestations of the 2019 Novel Coronavirus Disease (COVID-19):A MultiCenter Study in Wenzhou City, Zhejiang, China. J Infect 2020, 80, 388-393, https://doi.org/10.1016/j.jinf.2020.02.016.

49. Amrane, S.; Tissot-Dupont, H.; Doudier, B.; Eldin, C.; Hocquart, M.; Mailhe, M.; Dudouet, P.; Ormières, E.; Ailhaud, L.; Parola, P.; Lagier, J.-C.; Brouqui, P.; Zandotti, C.; Ninove, L.; Luciani, L.; Boschi, C.; La Scola, B.; Raoult, D.; Million, M.; Colson, P.; Gautret, P. Rapid Viral Diagnosis and Ambulatory Management of Suspected COVID-19 Cases Presenting at the Infectious Diseases Referral Hospital in Marseille, France, - January 31st to March 1st, 2020: A Respiratory Virus Snapshot. Travel Med Infect Dis 2020, 36, https://doi.org/10.1016/j.tmaid.2020.101632.

50. Ding, Y.; He, L.; Zhang, Q.; Huang, Z.; Che, X.; Hou, J.; Wang, H.; Shen, H.; Qiu, L.; Li, Z.; Geng, J.; Cai, J.; Han, H.; Li, X.; Kang, W.; Weng, D.; Liang, P.; Jiang, S. Organ Distribution of Severe Acute Respiratory Syndrome (SARS) Associated Coronavirus (SARS-CoV) in SARS Patients: Implications for Pathogenesis and Virus Transmission Pathways. J Pathol 2004, 203, 622-630, https://doi.org/10.1002/path.1560.

51. Tian, S.; Hu, W.; Niu, L.; Liu, H.; Xu, H.; Xiao, S.-Y. Pulmonary Pathology of Early-Phase 2019 Novel Coronavirus (COVID-19) Pneumonia in Two Patients With Lung Cancer. J Thorac Oncol 2020, 15, 700704, https://doi.org/10.1016/j.jtho.2020.02.010.

52. Ding, Y.; Wang, H.; Shen, H.; Li, Z.; Geng, J.; Han, H.; Cai, J.; Li, X.; Kang, W.; Weng, D.; Lu, Y.; Wu, D.; He, L.; Yao, K. The Clinical Pathology of Severe Acute Respiratory Syndrome (SARS): A Report from China. J Pathol 2003, 200, 282-289, https://doi.org/10.1002/path.1440.

53. Gu, J.; Gong, E.; Zhang, B.; Zheng, J.; Gao, Z.; Zhong, Y.; Zou, W.; Zhan, J.; Wang, S.; Xie, Z.; Zhuang, H.; Wu, B.; Zhong, H.; Shao, H.; Fang, W.; Gao, D.; Pei, F.; Li, X.; He, Z.; Xu, D.; Shi, X.; Anderson, V. M.; Leong, A.S.-Y. Multiple Organ Infection and the Pathogenesis of SARS. J Exp Med 2005, 202, 415424, https://doi.org/10.1084/jem.20050828.

54. Zhou, P.; Yang, X.-L.; Wang, X.-G.; Hu, B.; Zhang, L.; Zhang, W.; Si, H.-R.; Zhu, Y.; Li, B.; Huang, C.L.; Chen, H.-D.; Chen, J.; Luo, Y.; Guo, H.; Jiang, R.-D.; Liu, M.-Q.; Chen, Y.; Shen, X.-R.; Wang, X.; Zheng, X.-S.; Zhao, K.; Chen, Q.-J.; Deng, F.; Liu, L.-L.; Yan, B.; Zhan, F.-X.; Wang, Y.-Y.; Xiao, G.-F.; Shi, Z.-L. A Pneumonia Outbreak Associated with a New Coronavirus of Probable Bat Origin. Nature 2020, 579, 270-273, https://doi.org/10.1038/s41586-020-2012-7.

55. Conti, P.; Ronconi, G.; Caraffa, A.; Gallenga, C.; Ross, R.; Frydas, I.; Kritas, S. Induction of ProInflammatory Cytokines (IL-1 and IL-6) and Lung Inflammation by Coronavirus-19 (COVI-19 or SARSCoV-2): Anti-Inflammatory Strategies. J Biol Regul Homeost Agents 2020, 34, https://doi.org/10.23812/conti-e.

56. Huang, C.; Wang, Y.; Li, X.; Ren, L.; Zhao, J.; Hu, Y.; Zhang, L.; Fan, G.; Xu, J.; Gu, X.; Cheng, Z.; Yu, T.; Xia, J.; Wei, Y.; Wu, W.; Xie, X.; Yin, W.; Li, H.; Liu, M.; Xiao, Y.; Gao, H.; Guo, L.; Xie, J.; Wang, G.; Jiang, R.; Gao, Z.; Jin, Q.; Wang, J.; Cao, B. Clinical Features of Patients Infected with 2019 Novel Coronavirus in Wuhan, China. The Lancet 2020, 395, 497-506, https://doi.org/10.1016/S01406736(20)30183-5.

57. Davidson, S.; Maini, M.K.; Wack, A. Disease-Promoting Effects of Type I Interferons in Viral, Bacterial, and Co-infections. J Interferon Cytokine Res 2015, 35, 252-264, https://doi.org/10.1089/jir.2014.0227.

58. Fan, C.; Li, K.; Ding, Y.; Lu, W. L.; Wang, J. ACE2 Expression in Kidney and Testis May Cause Kidney and Testis Damage After 2019-NCoV Infection. medRxiv 2020, https://doi.org/10.1101/2020.02.12.20022418.

59. Li, Z.; Yao, J.; Guo, J.; Liao, X.; Song, S.; Li, J.; Duan, G.; Zhou, Y.; Wu, X.; Zhou, Z.; Wang, T.; Hu, M.; Chen, X.; Fu, Y.; Lei, C.; Dong, H.; Xu, C.; Hu, Y.; Han, M.; Zhou, Y.; Jia, H.; Chen, X.; Yan, J. Caution on Kidney Dysfunctions of COVID-19 Patients. preprint; Infectious Diseases (except HIV/AIDS) 2020, https://doi.org/10.1101/2020.02.08.20021212.

60. Diao, B.; Wang, C.; Wang, R.; Feng, Z.; Tan, Y.; Wang, H.; Wang, C.; Liu, L.; Liu, Y.; Liu, Y.; Wang, G.; Yuan, Z.; Ren, L.; Wu, Y.; Chen, Y. Human Kidney Is a Target for Novel Severe Acute Respiratory Syndrome Coronavirus 2 (SARS-CoV-2) Infection. preprint; Infectious Diseases (except HIV/AIDS) 2020, https://doi.org/10.1101/2020.03.04.20031120.

61. Tipnis, S.R.; Hooper, N.M.; Hyde, R.; Karran, E.; Christie, G.; Turner, A.J. A Human Homolog of Angiotensin-Converting Enzyme Cloning And Functional Expression As A Captopril-Insensitive Carboxypeptidase. J Biol Chem 2000, 275, 33238-33243, https://doi.org/10.1074/jbc.M002615200. 
62. Zhang, C.; Shi, L.; Wang, F.-S. Liver Injury in COVID-19: Management and Challenges. Lancet Gastroenterol Hepatol 2020, 5, 428-430, https://doi.org/10.1016/S2468-1253(20)30057-1.

63. Darmon, M.; Legrand, M.; Coudrot, M.; Zeni, F. Conséquences de l'hypoxémie aiguë sur la fonction rénale. Réanimation 2009, 18, 524-531, https://doi.org/10.1016/j.reaurg.2009.06.005.

64. Kuo, Y.-L.; Jou, I.-M.; Jeng, S.-F.; Chu, C.-H.; Huang, J.-S.; Hsu, T.-I.; Chang, L.-R.; Huang, P.-W.; Chen, J.-A.; Chou, T.-M. Hypoxia-Induced Epithelial-Mesenchymal Transition and Fibrosis for the Development of Breast Capsular Contracture. Sci Rep 2019, 9, 1-6, https://doi.org/10.1038/s41598-019-46439-7.

65. Khouchlaa, A.; Bouyahya, A. COVID-19 Nephropathy: Probable Mechanisms of Kidney Failure. 2020, 9 , 35. https://doi.org/10.34172/jnp.2020.35.

66. Cheng, Y.; Luo, R.; Wang, K.; Zhang, M.; Wang, Z.; Dong, L.; Li, J.; Yao, Y.; Ge, S.; Xu, G. Kidney Impairment Is Associated with In-Hospital Death of COVID-19 Patients. medRxiv 2020, https://doi.org/10.1101/2020.02.18.20023242.

67. Tucker, P.S.; Scanlan, A.T.; Dalbo, V.J. Chronic Kidney Disease Influences Multiple Systems: Describing the Relationship between Oxidative Stress, Inflammation, Kidney Damage, and Concomitant Disease. Oxidative Medicine and Cellualar Longevity 2015, 2015, https://doi.org/10.1155/2015/806358.

68. Huang, C.; Wang, Y.; Li, X.; Ren, L.; Zhao, J.; Hu, Y.; Zhang, L.; Fan, G.; Xu, J.; Gu, X.; Cheng, Z.; Yu, T.; Xia, J.; Wei, Y.; Wu, W.; Xie, X.; Yin, W.; Li, H.; Liu, M.; Xiao, Y.; Gao, H.; Guo, L.; Xie, J.; Wang, G.; Jiang, R.; Gao, Z.; Jin, Q.; Wang, J.; Cao, B. Clinical Features of Patients Infected with 2019 Novel Coronavirus in Wuhan, China. The Lancet 2020, 395, 497-506, https://doi.org/10.1016/S01406736(20)30183-5.

69. Wan, S.; Yi, Q.; Fan, S.; Lv, J.; Zhang, X.; Guo, L.; Lang, C.; Xiao, Q.; Xiao, K.; Yi, Z.; Qiang, M.; Xiang, J.; Zhang, B.; Chen, Y. Characteristics of Lymphocyte Subsets and Cytokines in Peripheral Blood of 123 Hospitalized Patients with 2019 Novel Coronavirus Pneumonia (NCP). medRxiv 2020, https://doi.org/10.1101/2020.02.10.20021832.

70. Xiong, Y.; Liu, Y.; Cao, L.; Wang, D.; Guo, M.; Jiang, A.; Guo, D.; Hu, W.; Yang, J.; Tang, Z.; Wu, H.; Lin, Y.; Zhang, M.; Zhang, Q.; Shi, M.; Liu, Y.; Zhou, Y.; Lan, K.; Chen, Y. Transcriptomic Characteristics of Bronchoalveolar Lavage Fluid and Peripheral Blood Mononuclear Cells in COVID-19 Patients. Emerg. Microbes Infect 2020, 9, 761-770, https://doi.org/10.1080/22221751.2020.1747363.

71. Wang, X.; Xu, W.; Hu, G.; Xia, S.; Sun, Z.; Liu, Z.; Xie, Y.; Zhang, R.; Jiang, S.; Lu, L. SARS-CoV-2 Infects T Lymphocytes through Its Spike Protein-Mediated Membrane Fusion. Cell Mol Immunol 2020, 13, https://doi.org/10.1038/s41423-020-0424-9.

72. Guan, W.; Ni, Z.; Hu, Y.; Liang, W.; Ou, C.; He, J.; Liu, L.; Shan, H.; Lei, C.; Hui, D. S.; Du, B.; Li, L.; Zeng, G.; Yuen, K.-Y.; Chen, R.; Tang, C.; Wang, T.; Chen, P.; Xiang, J.; Li, S.; Wang, J.; Liang, Z.; Peng, Y.; Wei, L.; Liu, Y.; Hu, Y.; Peng, P.; Wang, J.; Liu, J.; Chen, Z.; Li, G.; Zheng, Z.; Qiu, S.; Luo, J.; Ye, C.; Zhu, S.; Zhong, N. Clinical Characteristics of 2019 Novel Coronavirus Infection in China. medRxiv 2020, https://doi.org/10.1101/2020.02.06.20020974.

73. Lin, L.; Jiang, X.; Zhang, Z.; Huang, S.; Zhang, Z.; Fang, Z.; Gu, Z.; Gao, L.; Shi, H.; Mai, L.; Liu, Y.; Lin, X.; Lai, R.; Yan, Z.; Li, X.; Shan, H. Gastrointestinal Symptoms of 95 Cases with SARS-CoV-2 Infection. Gut 2020, https://doi.org/10.1136/gutjnl-2020-321013.

74. Song, Y.; Liu, P.; Shi, X.L.; Chu, Y.L.; Zhang, J.; Xia, J.; Gao, X.Z.; Qu, T.; Wang, M.Y. SARS-CoV-2 Induced Diarrhoea as Onset Symptom in Patient with COVID-19. Gut 2020. https://doi.org/10.1136/gutjnl2020-320891.

75. Hamming, I.; Timens, W.; Bulthuis, M.L.C.; Lely, A.T.; Navis, G.J.; Goor, H.van. Tissue Distribution of ACE2 Protein, the Functional Receptor for SARS Coronavirus. A First Step in Understanding SARS Pathogenesis. J Pathol 2004, 203, 631-637, https://doi.org/10.1002/path.1570.

76. Xu, Z.; Shi, L.; Wang, Y.; Zhang, J.; Huang, L.; Zhang, C.; Liu, S.; Zhao, P.; Liu, H.; Zhu, L.; Tai, Y.; Bai, C.; Gao, T.; Song, J.; Xia, P.; Dong, J.; Zhao, J.; Wang, F.-S. Pathological Findings of COVID-19 Associated with Acute Respiratory Distress Syndrome. Lancet Respir Med 2020, 8, 420-422, https://doi.org/10.1016/S2213-2600(20)30076-X.

77. Netland, J.; Meyerholz, D.K.; Moore, S.; Cassell, M.; Perlman, S. Severe Acute Respiratory Syndrome Coronavirus Infection Causes Neuronal Death in the Absence of Encephalitis in Mice Transgenic for Human ACE2. J Virol 2008, 82, 7264-7275, https://doi.org/10.1128/JVI.00737-08.

78. Xu, J.; Qi, L.; Chi, X.; Yang, J.; Wei, X.; Gong, E.; Peh, S.; Gu, J. Orchitis: A Complication of Severe Acute Respiratory Syndrome (SARS). Biol Reprod 2006, 74, 410-416.

79. Watzinger, F.; Suda, M.; Preuner, S.; Baumgartinger, R.; Ebner, K.; Baskova, L.; Niesters, H.G.M.; Lawitschka, A.; Lion, T. Real-Time Quantitative PCR Assays for Detection and Monitoring of Pathogenic Human Viruses in Immunosuppressed Pediatric Patients. J Clin Microbiol 2004, 42, 5189-5198, https://doi.org/10.1128/JCM.42.11.5189-5198.2004.

80. Li, Z.; Yi, Y.; Luo, X.; Xiong, N.; Liu, Y.; Li, S.; Sun, R.; Wang, Y.; Hu, B.; Chen, W.; Zhang, Y.; Wang, J.; Huang, B.; Lin, Y.; Yang, J.; Cai, W.; Wang, X.; Cheng, J.; Chen, Z.; Sun, K.; Pan, W.; Zhan, Z.; Chen, L.; Ye, F. Development and Clinical Application of a Rapid IgM-IgG Combined Antibody Test for SARSCoV-2 Infection Diagnosis. J Med Virol 2020, https://doi.org/10.1002/jmv.25727. 
81. Hosseiny, M.; Kooraki, S.; Gholamrezanezhad, A.; Reddy, S.; Myers, L. Radiology Perspective of Coronavirus Disease 2019 (COVID-19): Lessons From Severe Acute Respiratory Syndrome and Middle East Respiratory Syndrome. Am J Roentgenol 2020, 1-5, https://doi.org/10.2214/AJR.20.22969.

82. Hosseiny, M.; Kooraki, S.; Gholamrezanezhad, A.; Reddy, S.; Myers, L. Radiology Perspective of Coronavirus Disease 2019 (COVID-19): Lessons From Severe Acute Respiratory Syndrome and Middle East Respiratory Syndrome. Am J Roentgenol 2020, 1-5. https://doi.org/10.2214/AJR.09.4110. 